$12-2-2021$

\title{
Positive Charter Rights: When Can We Open the "Door?"
}

Michael Da Silva

University of Ottawa

Follow this and additional works at: https://digitalcommons.osgoode.yorku.ca/ohlj

Part of the Law Commons

Article

\section{(c) (1) $(9$}

This work is licensed under a Creative Commons Attribution-Noncommercial-No Derivative Works 4.0 License.

\section{Citation Information}

Da Silva, Michael. "Positive Charter Rights: When Can We Open the "Door?"." Osgoode Hall Law Journal 58.3 (2021) : 669-717.

https://digitalcommons.osgoode.yorku.ca/ohlj/vol58/iss3/4

This Article is brought to you for free and open access by the Journals at Osgoode Digital Commons. It has been accepted for inclusion in Osgoode Hall Law Journal by an authorized editor of Osgoode Digital Commons. 


\title{
Positive Charter Rights: When Can We Open the "Door?"
}

\begin{abstract}
Whether the Supreme Court of Canada can and should recognize so-called "positive" rights (viz., rights that require the performance of certain actions, possibly including the provision of goods, by the government) under the Canadian Charter of Rights and Freedoms remains contentious. Binding Supreme Court precedent states that there are no positive Charter rights-at least under sections 7, 12, and 15, under which demands for positive action are most controversially raised-but positive aspects of Charter rights could be recognized in the future. Yet the circumstances under which such recognition would be appropriate remain opaque. This work suggests that the law of precedent is a helpful tool for examining when recognition of positive rights could be justified from both the institutional perspective of the Court's internal norms and from an all-things-considered perspective. It is, at minimum, a useful framing mechanism for exploring the most difficult issues concerning the recognition of positive rights. Interestingly, application of the test for going against precedent suggests a break between when the Court could recognize positive rights according to its own norms and when doing so would be justified, all things considered. Yet, more importantly, the considerations raised by the law of precedent test also highlight a burden on future all-things-considered recognition of positive rights and demonstrate how the judiciary could avoid the potential negative consequences of their recognition.
\end{abstract}

\section{Creative Commons License} (c) (i) $\odot$

This work is licensed under a Creative Commons Attribution-Noncommercial-No Derivative Works 4.0 License. 


\title{
Positive Charter Rights: When Can We Open the "Door?"
}

\author{
MICHAEL DA SILVA
}

Whether the Supreme Court of Canada can and should recognize so-called "positive" rights (viz., rights that require the performance of certain actions, possibly including the provision of goods, by the government) under the Canadian Charter of Rights and Freedoms remains contentious. Binding Supreme Court precedent states that there are no positive Charter rights-at least under sections 7, 12, and 15, under which demands for positive action are most controversially raised-but positive aspects of Charter rights could be recognized in the future. Yet the circumstances under which such recognition would be appropriate remain opaque. This work suggests that the law of precedent is a helpful tool for examining when recognition of positive rights could be justified from both the institutional perspective of the Court's internal norms and from an all-things-considered perspective. It is, at minimum, a useful framing mechanism for exploring the most difficult issues concerning the recognition of positive rights. Interestingly, application of the test for going against precedent suggests a break between when the Court could recognize positive rights according to its own norms and when doing so would be justified, all things considered. Yet, more importantly, the considerations raised by the law of precedent test also highlight a burden on future all-things-considered recognition of positive rights and demonstrate how the judiciary could avoid the potential negative consequences of their recognition.

Alex Trebek Postdoctoral Fellow in AI and Healthcare and Research Associate, University of Ottawa. This article was written when I was the Canadian Institutes of Health Research Postdoctoral Fellow in the McGill University Faculty of Law and Institute for Health and Social Policy. It was accepted when I was the Alex Trebek Postdoctoral Fellow in AI and Healthcare and a Research Associate in the Faculty of Law, Centre for Law, Society and Technology, and Centre for Health Law, Policy and Ethics at the University of Ottawa. I accordingly completed final edits while at the University of Ottawa. I thank these institutions for their support. I also thank Daniel Weinstock, an audience at the Western University Faculty of Law, and anonymous reviewers for the Osgoode Hall Law Journal for helpful comments on this article and Colleen M Flood, Sophia Moreau, and Lorraine Weinrib for comments on related work. Finally, I thank the editorial team at the Osgoode Hall Law Journal for their efforts on the article. 
I. CANADIAN POSITIVE RIGHTS JURISPRUDENCE: A BRIEF OVERVIEW......

II. BURDENS FOR POSSIBLE RECOGNITION.....

III. PRECEDENT AS A GUIDE TO APPROPRIATE RECOGNITION OF POSITIVE RIGHTS.

IV. APPLYING THE TEST

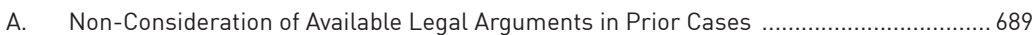

B. Changes in Legal Doctrine Such That Aspects of a Prior Law Were Not Addressed ........690

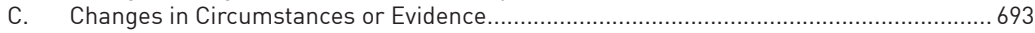

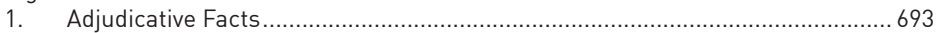

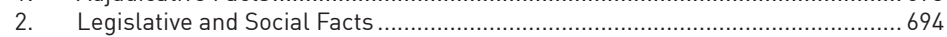

V. IMPLICATIONS FOR AN ALL-THINGS-CONSIDERED ANALYSIS OF POSITIVE RIGHTS ..... 705

VI. CONCLUSION

CONTEMPORARY CANADIAN POLITICS AND LAW highlight the importance of attending to rights-based claims for basic social goods like health care and housing. COVID-19 highlighted that many Canadians' access to these goods is precarious at best. Governmental spending on the provision of these goods, sometimes on non-constitutional rights-based grounds, has not ensured sufficient access thereto or equal access across the provinces. ${ }^{1}$ Demands for "rights" to social goods are thus

1. Cursory glances at pandemic-era headlines and press releases make this clear. The Canadian Human Rights Commission released a statement entitled "Inequality amplified during COVID-19" that highlighted unequal — and at times insufficient_-access to housing and health care as key examples of inequities exacerbated by COVID-19. (31 March 2020), online: Canadian Human Rights Commission <www.chrc-ccdp.gc.ca/en/resources/ inequality-amplified-covid-19-crisis $>$. Advocacy for increased and adequate health care coverage for vulnerable groups, housing for the homeless, and limits on evictions also occurred during the early months of the COVID-19 pandemic. See e.g. Colin Perkel, "Provinces urged to give newcomers prompt access to public health insurance," The Globe and Mail (19 March 2020), online: <www.theglobeandmail.com/canada/article-provincesurged-to-scrap-wait-period-for-newcomers-to-access-public >; Public Service Alliance of Canada, "COVID-19: Better access to health care, housing needed across the North" (23 March 2020), online: <psacunion.ca/covid-19-better-access-healthcare-housingneeded >; The Canadian Press, "COVID-19 highlights existing barriers for Canadians with communication disabilities," CTV News (7 May 2020), online: <www.ctvnews.ca/health/ coronavirus/covid-19-highlights-existing-barriers-for-canadians-with-communicationdisabilities-1.4929736>; Morgan Lowrie, "COVID-19, surge in 'renovictions,' complicate Montreal's traditional moving day," The Globe and Mail (1 July 2020), online: <www. theglobeandmail.com/canada/article-covid-19-surge-in-renovictions-complicate-montrealstraditional-2>; Trevor Morey \& Naheed Dosani, "Access to housing is not just a political issue. COVID-19 has made it a matter of life and death," CBC (1 September 2020), online: <www.cbc.ca/news/opinion/opinion-homeless-strategy-1.5701372>. As I complete final revisions of this article, differential access to vaccinations is an issue, though whether that will remain so is difficult to predict. 
unsurprising: Many Canadians believe governments are duty-bound to ensure adequate access to health care or housing, either directly or through the provision of a basic income. ${ }^{2}$ Such claimed entitlements, of course, predate COVID-19. For instance, an alternative rights-based argument for less governmental involvement in health care was challenging traditional Canadian constitutional and health law prior to the pandemic. The release of Cambie Surgeries Corporation v. British Columbia (Attorney General) ("Cambie") in the midst of concerns about COVID-19's second wave was a stark reminder of how "rights" language can be used for competing ends in social policy debates. ${ }^{3}$ Cambie's years-long challenge to British Columbia's Medicare Protection Act $(M P A)^{4}$ is, in part, a claim that there is a right to timely access to health care that is only realizable when private clinicians can operate in both public and private health care settings. ${ }^{5}$ The trial court viewed it as "tantamount to a claim of a constitutional right to

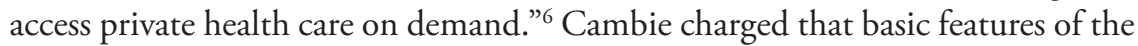
Canadian Medicare system, as embodied in the federal Canada Health $\mathrm{Act}^{7}$ and implemented in British Columbia by the $M P A$, limit access to health care and thus violate Canadians' constitutional rights. ${ }^{8}$ Cambie's critics suggest that rights

2. Ibid. This is also clear in pre-pandemic works, but features in more academic, though not always Canada-specific, analyses of COVID-19 law or ethics. See especially Colleen M Flood et al, eds, Vulnerable: The Law, Policy and Ethics of COVID-19 (University of Ottawa Press, 2020); Meredith Celene Schwartz, ed, The Ethics of Pandemics (Broadview Press, 2020). On the basic income proposal in Canada, see e.g. Graham Riches, "Canada must eliminate food banks and provide a basic income after COVID-19," The Conversation (10 September 2020), online: <theconversation.com/canada-must-eliminate-foodbanks-and-provide-a-basic-income-after-covid-19-144994>; Jessie Willms \& Hailey Montgomery, "Senators tell Ottawa to consider a universal basic income for economic recovery," The Globe and Mail (14 July 2020), online: <www.theglobeandmail.com/canada/ article-coronavirus-update-senators-tell-ottawa-to-consider-a-universal-basic>.

3. 2020 BCSC 1310 [Cambie].

4. RSBC 1996, с $286[M P A]$.

5. Cambie, supra note 3. The case is expected to eventually reach the Supreme Court of Canada. Cambie has already begun the appeals process. See also Colleen M Flood \& YY Brandon Chen, "Charter Rights \& Health Care Funding: A Typology of Canadian Health Rights Litigation” (2010) 19 Ann Health L 479 at 508 (also detailing earlier attempts to undermine Medicare through rights claims).

6. Cambie, supra note 3 at para 1728.

7. RSC 1985, c C-6.

8. Cambie, supra note 3. Cambie challenges the MPA, through which criteria for federal funding for provincial health care systems in the Canada Health Act are "written directly into provincial law." See William Lahey, "Medicare and the Law: Contours of an Evolving Relationship" in Jocelyn Downie, Timothy Caulfield \& Colleen M Flood, eds, Canadian Health Law and Policy, 4th ed (LexisNexis Canada, 2011) 1 at 51. A fifth edition of this textbook is now available, but some pieces in the earlier edition retain their importance. 
to access private health care providers will undermine access to health care for most Canadians and advocate for a "positive" right to health care goods to avoid Cambie's misuse of rights language to undermine access. " Large sections of the trial judgment engaged with these empirical debates. ${ }^{10}$ Yet the broader concerns also reflect theoretical differences regarding the basic social goods to which persons should be entitled - a point that the trial judgment decision sought to avoid where possible. ${ }^{11}$ Judges will likely consider these differences in years-long appeals (even if they follow the trial-level decision and try to avoid framing the underlying concerns in terms of positive social rights). ${ }^{12}$

These developments invite reconsideration of past arguments about the possibility of rights to basic social goods in Canadian constitutional law. This article conducts such an analysis by examining both the relevant jurisprudence and how the internal logic of the Supreme Court of Canada's (SCC) past pronouncements limit its ability to recognize certain "positive" rights claims. For decades, the SCC has both refused to recognize "positive rights" to the performance of certain actions (possibly including the provision of certain goods) under the Canadian Charter of Rights and Freedoms and said it could recognize

9. For different positions, see Colleen M Flood \& Bryan Thomas, eds, Is Two-Tier Health Care the Future? (University of Ottawa Press, 2020) [Flood \& Thomas, Two-Tier]. For a strong critical analysis, see Martha Jackman, "Chaoulli to Cambie: Charter Challenges to the Regulation of Private Care" in Flood \& Thomas, Two-Tier, supra note 9, 37 [Jackman, "Chaoulli"].

10. Cambie, supra note 3. See especially ibid, section F.

11. See e.g. Flood \& Thomas, Two-Tier, supra note 9. Cambie, supra note 3 at para 1728 (highlighting a different view on the "right" to health care than that which is traditionally found in social rights scholarship). Note that Cambie et al hold that, on the empirical evidence, allowing private health care will improve the performance of the public health care system. See e.g. Jackman, "Chaoulli," supra note 9 at 43. The judgment in Cambie found this unpersuasive. Supra note 3. For another critical analysis of the underlying claim, viewing it as a cash grab, see Marie-Claude Prémont \& Cory Verbauwhede, "Canadian Legislatures and the Regulation of the Private Health-care Industry” (2018) 68 UTLJ 231.

12. Cambie, supra note 3 . The court largely sidesteps issues about positive rights except to note that "the scope of the rights under s. 7 may be considered unsettled" (ibid at para 2052). Appellate decisions may thus be able to avoid directly addressing positive claims, though the lack of sustained engagement on this point could equally prove to be a wedge through which Cambie can challenge the otherwise thorough trial-level decision. Lack of engagement also leaves the possibility of other positive rights claims open. See Colleen M Flood \& Bryan Thomas, "A Successful Charter Challenge to Medicare? Policy Options for Canadian Provincial Governments" (2018) 13 Health Econ Pol'y \& L 433. Flood \& Thomas detail possible legislative responses to any eventual Cambie "win." 
them in the future. ${ }^{13}$ Wide, fruitful literatures analyze the state of constitutional positive rights recognition in Canada, including the history of claims to specific rights and normative cases for recognition for either the general population or specific groups. ${ }^{14}$ Yet jurisprudential guidance on when it would be appropriate to recognize positive rights is lacking.

The test for going against past precedent provides a useful starting point for analyzing positive rights claims. The modern test first appeared in Canada (Attorney General) v. Bedford ("Bedford") ${ }^{15}$ - a case that overturned the precedent set in the "Prostitution Reference" and established a (negative) right to be free from criminal sanction for some activities related to sex work. ${ }^{16}$ The test states that changes in law, facts, or both can justify a departure from precedent by

13. See Canadian Charter of Rights and Freedoms, Part I of the Constitution Act, 1982, being Schedule B to the Canada Act 1982 (UK), 1982, c 11 [Charter]. I discuss relevant case law below.

14. See e.g. Martha Jackman \& Bruce Porter, "Canada: Socio-Economic Rights Under the Canadian Charter" in Malcolm Langford, ed, Social Rights Jurisprudence: Emerging Trends in International and Comparative Law (Cambridge University Press, 2008) 209. The right to health care alone raises numerous examples, see e.g. Martha Jackman, "The Right to Participate in Health Care and Health Resource Allocation Decisions Under Section 7 of the Canadian Charter" (1995) 4 Health L Rev 3 [Jackman, "Right"]; Tamara Friesen, "The Right to Health Care" (2001) 9 Health LJ 205; Mel Cousins, "Health Care and Human Rights After Auton and Chaoulli" (2009) 54 McGill LJ 717; Nola M Ries, "Charter Challenges" in Downie, Caulfield \& Flood, supra note 8, 615; Colleen M Flood, "Litigating Health Rights in Canada: A White Knight for Equity?" in Colleen M Flood \& Aeyal Gross, eds, The Right to Health at the Public/Private Divide: A Global Comparative Study (Cambridge University Press, 2014) 79; Michael Da Silva, "A Goal-Oriented Understanding of the Claimed Right to Health Care and Its Implications for Future Health Rights Litigation" (2016) 39 Dal LJ 377 [Da Silva, "Goal"]; Martha Jackman, "Charter Review of Health Care Access" in Joanna Erdman, Vanessa Gruben \& Erin Nelson, eds, Canadian Health Law and Policy, 5th ed (LexisNexis Canada, 2017) 71; YY Brandon Chen, "The Future of Precarious Status Migrants' Right to Health Care in Canada" (2017) 54 Alta L Rev 649. See also my forthcoming book, The Pluralist Right to Health Care: A Framework and Case Study (University of Toronto Press, 2021) [Da Silva, Pluralist]. This book focuses on the purported right to health care. The book covers some of the same cases as the present article and contains a few paragraphs pointing to the analysis provided here. Unsurprisingly, I reach similar conclusions in both texts, but the book and article have different argumentative foci and strategies, so their overlap is minimal. For a good housing-based piece that is cited in Cambie, supra note 3, see Margot Young, "Charter Eviction: Litigating Out of House and Home" (2015) 24 J L \& Soc Pol'y 46.

15. 2013 SCC 72 [Bedford]. This decision overturned Reference re ss 193 and 195.1(1)(c) of the Criminal Code (Man), [1990] 1 SCR 1123 [Prostitution Reference].

16. Bedford, supra note 15 at paras 42, 44. 
presenting new legal issues. ${ }^{17}$ It offers a standard for appropriate future recognition of positive rights from the perspective of the institutional norms of precedent. Applying this test cannot provide an all-things-considered case for the recognition of positive rights. Judicial recognition of positive rights is likely fully justifiable only when such recognition can bring about some good. Yet the circumstances that justify overturning past precedent would at least make recognition of positive rights consistent with the SCC's avowed approaches to the Charter and doctrinal change. Examining whether any legal or factual changes raise new legal issues that warrant reconsideration of positive rights-a key component of any application of the test for going against past precedent-provides a means of judging future SCC statements on positive rights. The test further provides a framing mechanism for addressing other issues with such recognition that is necessary for any all-things-considered case.

My analysis begins with a brief discussion of Canada's positive rights jurisprudence. I then discuss some possible burdens associated with recognizing positive rights. I follow by explaining why the test for reconsidering past precedent is helpful for analyzing these burdens and outlining the test. I next apply the test to the case of positive Charter rights, largely taking existing precedent laws as parametric. ${ }^{18} \mathrm{I}$ conclude by discussing possible implications for all-things-considered analyses of positive rights. At each stage, I (provisionally) understand "positive" rights as those rights that require duty bearers to perform certain actions and "negative" rights as those that require duty bearers to refrain from certain actions. "Socio-economic" rights are understood as a class of positive rights requiring the provision of social goods. These definitions are imperfect (and I discuss works that challenge the positive-negative rights distinction below), but working definitions are necessary to conduct the present inquiry and my working definitions track existing constitutional orthodoxies.

17. This test summarizes doctrinal statements and applications in Bedford, supra note 15. See also Carter v Canada (AG), 2015 SCC 5 [Carter]. This decision overturned Rodriguez v British Columbia $(A G)$, [1993] 3 SCR 519 [Rodriguez]. See Part III, below, for nuances.

18. I will not canvass the massive literature on when courts can and should go against precedent in Canadian law. I will take the current test in Canadian constitutional law as a starting point and explore its implications for an underexplored issue. Citing every work on precedent is unwise given my narrower focus, but I incidentally add to the wider literature when arguing for interpretations of unclear parts of the current test. For a great overview of the test in constitutional law, see Debra Parkes, "Precedent Revisited: Carter v. Canada (AG) and the Contemporary Practices of Precedent" (2016) 10 McGill JL \& Health S123 (updating Debra Parkes, "Precedent Unbound? Contemporary Approaches to Precedent in Canada" (2007) 32 Man LJ 135). See also Lawrence David, Stare Decisis, The Charter and the Rule of Law in the Supreme Court of Canada (LexisNexis Canada, 2020). 
Ultimately, the time to recognize positive rights has likely come from the institutional perspective of the SCC's precedent-based norms, but recognition thereof as part of pre-existing Charter rights should be limited to avoid problems that could otherwise undermine any all-things-considered justification for constitutional social rights. The data that could justify going against past precedent also demonstrate that recognizing constitutional positive rights is not always an unqualified good. Attending to the stages of the "precedent test" fails to provide an all-things-considered case for recognizing positive rights and highlights other issues that the SCC should address if it chooses to recognize such rights. Courts should, in short, avoid recognizing positive rights unless they must address competing rights claims to resolve a case, and they should take a gradualist, purposive approach to positive rights, only recognizing narrowly tailored constitutional rights where there is ample evidence that recognition thereof will not raise problems with recognition that are seen elsewhere.

\section{CANADIAN POSITIVE RIGHTS JURISPRUDENCE: A BRIEF OVERVIEW}

The SCC's historical position on positive rights is clear. Notwithstanding some justices' recognition of positive elements of some rights, ${ }^{19}$ the rights that most advocates want to contain positive elements - the rights under sections 7,15 , and perhaps 12 of the Charter of Rights and Freedoms-clearly do not include positive dimensions; but they could someday. While scholars assert that the rights under sections 7 and 15 of the Charter, "which might otherwise be classified as 'civil and political,' are best understood in the Canadian context as including both civil and political and socio-economic dimensions, ${ }^{20}$ the judiciary has historically disagreed. Equivalents of the section 7 right "to life, liberty and security of the person and the right not to be deprived thereof except in accordance with the principles of fundamental justice" are used to fashion positive rights elsewhere. ${ }^{21}$

19. See e.g. Gosselin v Québec (AG), 2002 SCC 84 [Gosselin] (see Justice Arbour's dissent, especially ibid at para 320 ).

20. Jackman \& Porter, supra note 14 at 209 . Other sources in note 14 make similar claims.

21. India is the clearest example. See Francis Coralie Mullin v Administrator, Union Territory of Delhi \& Ors, [1981] 2 SCR 516 (India); Paschim Banga Khet Mazdoor Samity of Ors v State of West Bengal \& Anr, [1996] 4 SCR 37 (India); State of Punjab \& Ors v Mohinder Singh Chawla, [1997] 2 SCC 83 (India). Germany and Israel provide more controversial examples. Cf Gila Louzon v Government of Israel, [2008] HCJ 3071/05 (Israel); Bundesverfassungsgericht [Federal Constitutional Court], Karlsruhe, 18 July 2012, 1 BvL 10/10 (Germany). See also Flood \& Gross, supra note 14. 
Yet the constitutional prospects for such an expanded section 7 in Canada can be briefly summarized with two widely cited judicial statements. As noted by Chief Justice Beverley McLachlin and Justice John Major in Chaoulli v. Québec ("Chaoulli"), the Charter "does not confer a freestanding constitutional right to healthcare"22 or any other social good; but, as Chief Justice McLachlin wrote for the majority in Gosselin v. Québec (Attorney General) ("Gosselin"), a welfare case, "[o]ne day s. 7 may be interpreted to include positive obligations." ${ }^{33}$ Section 7 was used to decriminalize access to or provision of health care goods (viz. abortion services, safe injection sites, and assisted death) in negative-rights cases. ${ }^{24}$ Parts of those cases support guaranteed access to the decriminalized goods, which some read as positive entitlements. ${ }^{25}$ Canada (Attorney General) v. PHS Community Services Society ("Insite") famously required positive government action of a kind; there, the requirement that the Minister of Health renew the exemption from criminal prosecution for three safe injection sites, where otherwise-illegal drugs were moved and consumed, could be described as a positive requirement. ${ }^{26}$ But even Insite did not require the government to fund or otherwise support the safe injection sites, let alone other social goods like health care. ${ }^{27}$ The SCC has not clearly recognized a positive right to health care, housing, welfare benefits, or any other social good. The basic lesson of Gosselin and Chaoulli remains operative, and lower courts likewise continue to deny that section 7 includes a positive

22. [2005] 1 SCR 791 at para 104 [Chaoulli].

23. Supra note 19 at para 82 .

24. Rv Morgentaler, [1988] 1 SCR 30 [Morgentaler]; Canada (AG) v PHS Community Services Society, 2011 SCC 44 [Insite]; Carter, supra note 17. Flood \& Chen, supra note 5 at 483 identify Morgentaler as an example of the court recognizing a negative right. Insite and Carter arguably serve as examples of negative rights cases. Flood and Chen offer the lower-court decision in Insite as an example thereof. Supra note 5 at 483, 497.

25. See e.g. Lorraine E Weinrib, "The Morgentaler Judgment: Constitutional Rights, Legislative Intention, and Institutional Design" (1992) 42 UTLJ 22. Weinrib reads Morgentaler as being based on "a politically neutral constitutional guarantee of unimpeded access to health care" (ibid at 32).

26. Insite, supra note 24 .

27. Ibid. 
component, while recognizing that the "door" to positive rights recognition remains "slightly ajar" (as the Court of Appeal for Ontario put it more recently). ${ }^{28}$ The "door" to positive entitlements under section 15, which guarantees equality "before and under the law and ... the equal protection and equal benefit of the law without discrimination," is also only narrowly ajar. ${ }^{29}$ While some case law suggests that section 15 guarantees entitlements to the goods necessary to enjoy other entitlements belonging to others, this positive element is rarely recognized. The SCC famously held that section 15 guarantees access to translation services for the deaf in hospitals in Eldridge v. British Columbia (Attorney General) ("Eldridge"), ${ }^{30}$ but Auton v. British Columbia (Attorney General) ("Auton") quickly limited progressive readings thereof. ${ }^{31}$ Per Auton, section 15 does not require provision of the goods necessary to access the health care system in the first instance or of any particular goods; "positive" constitutional "rights" require pre-existing statutory entitlements. ${ }^{32}$ Whether other changes in section 15 doctrine challenge this finding is unclear.

28. Tanudjaja $v$ Canada, 2014 ONCA 852 at para 37. Despite claimed violations of sections 7 and 15 , the court found no reasonable cause of action in the case at bar, a denial of housing benefits, and struck the relevant motion. The majority judgment recognized that the door was ajar but suggested that there was no need to consider the extent to which the Charter could confer positive obligations in that case. The reasons given for why the claims were not justiciable seemingly assumed that sections 7 and 15 could not have these positive components. This assumption is much weaker than earlier lower-court decisions, which suggest that section 7 "cannot" include a positive component. See e.g. Brown v British Columbia (Minister of Health), [1990] BCJ No 151 (BCSC) (a claim for access to the HIV drug AZT similarly failed on the grounds that the plaintiffs were "seeking a 'benefit' which may enhance life, liberty or security of the person, which s. 7 cannot provide" at para 146. The section 15 claim also failed).

See also Florav Ontario (Health Insurance Plan, General Manager), 2008 ONCA 538. Courts even deny this when they acknowledge that persons have a right of access to a health care regime. Covarrubias v Canada (Minister of Citizenship and Immigration), [2007] 3 FCR 169; Canadian Doctors for Refugee Care v Canada (AG), 2014 FC 651 [Refugee Care]. Yet other cases deny that one has a right to access a good or a regime. See e.g. Toussaint v Canada (AG), [2013] 1 FCR 374. Also recall the statement from Cambie, supra note 12.

29. Charter, supra note 13, s 15.

30. [1997] 3 SCR 624 [Eldridge]. Whether such services qualify as health care goods is debatable at best. The logic of the case can, in any event, be used to form an argument for recognition of health care goods that fill a similar role.

31. 2004 SCC 78 at para 41 [Auton].

32. The massive literature on Eldridge, Auton, and Chaoulli rarely discusses the present issue. But, for excellent overviews of the cases, their impact, and scholarly commentary thereon, see Christopher P Manfredi \& Antonia Maioni, Health Care and the Charter: Legal Mobilization and Policy Change in Canada (UBC Press, 2018). 
Finally, section 12 could have positive elements, but the SCC has yet to consider them. In Canadian Doctors for Refugee Care v. Canada (Attorney General) ("Refugee Care"), the Federal Court of Canada found that proposed cuts to the Interim Federal Health Program, a supplementary health care program for refugee claimants, violated section 12's right to be free from "cruel and unusual treatment." 33 The cuts violated the claimants' right by seeking "to make the lives of disadvantaged individuals even more difficult...in an effort to force those who have sought the protection of this country to leave Canada more quickly, and to deter others from coming here," thereby jeopardizing "the health... [and] lives, of...innocent and vulnerable children." ${ }^{34}$ Comparable cuts to other health care programs may similarly violate section 12 , creating de facto positive rights to access a health care system. If non-provision of goods constitutes "cruel and unusual treatment" - at least in narrow circumstances such as where the goods were previously provided to a group, are necessary for basic sustenance, and are otherwise unavailable to group members-provision of those goods appears to be the only plausible remedy. Yet the SCC rarely considers section 12's freedom from cruel and unusual treatment branch and has not ruled on whether it contains positive components. Moreover, even Refugee Care could be understood as recognizing negative rights: One could plausibly read the case as guaranteeing freedom from arbitrary interference with one's access to the medically necessary health care services to which one was previously entitled under the law. ${ }^{35}$

The SCC provides little guidance as to when the "doors" to positive rights recognition under sections 7,12 , or 15 should be "opened" to new inquiries. There is a sense in which the SCC itself determines the appropriate burden for recognizing positive rights: The Court can always change its mind about

33. Refugee Care, supra note 28 (addressing Order Respecting the Interim Federal Health Program, 2012, SI/2012-26).

34. Refugee Care, supra note 28 at paras 689-91, relying on Charter, supra note 13, s 12 . The FCC also notably held that limiting the coverage of claimants from Designated Countries of Origin to services required for "Public Health or Public Safety" violated section 15 of the Charter's right to equality and freedom from discrimination on the basis of national origin by risking the lives of those claimants and perpetuating the stereotype that they were "cheats." Ibid at paras 692-872. I read this as consistent with Auton's requirement of a pre-existing benefit and thus do not highlight it in the main text: The program did not provide benefits to claimants from those countries that it was providing to others on the basis of a protected characteristic.

35. See Refugee Care, supra note 28 (and the general discussion of the section 12 case law in Parts $\mathrm{IV}(\mathrm{B})$ and $\mathrm{V}$, below). 
recognition. ${ }^{36}$ While the executive and legislative governments have powers that can limit the scope of SCC decisions, the SCC possesses the formal power to interpret the constitution in new ways. There is no formal bar against recognition except the constitutional text and past precedent; the SCC ultimately resolves debates about both. ${ }^{37}$ Potential barriers to justifiable recognition should nonetheless be addressed in any analysis of relevant SCC decision making. The precedent test is a helpful framing mechanism for analyzing those barriers, to which I now turn.

\section{BURDENS FOR POSSIBLE RECOGNITION}

Arguments for "positive" rights recognition should address various persistent challenges. These issues can be classified as conceptual, institutional, and jurisprudential. Such simplifying classifications helpfully organize the most basic concerns. The quantum of challenges a litigant must address to secure positive rights under the Charter remains debatable, but any case for recognition should at least plausibly be capable of addressing some persistent challenges.

First, while some ethical or political issues may be beyond judicial purview, the underlying concerns are relevant to the evaluation of judicial decisions. ${ }^{38}$

36. Thank you to an audience at the Western University Faculty of Law for discussion of this point. Thank you also to an anonymous reviewer for this Journal, who further highlighted and stressed this possibility.

37. The relationships between different branches of government and the scope of the branches' respective powers are highly contested. Yet all parties agree that courts can interpret the constitution, that judicial review for compliance therewith is appropriate, and that other branches of government can limit the scope of judicial determinations in at least Charter-based cases. Discussion of "dialogue theory" is helpful. See e.g. Peter W Hogg \& Ravi Amarnath, "Understanding Dialogue Theory" in Peter Oliver, Patrick Macklem \& Nathalie Des Rosiers, eds, The Oxford Handbook of the Canadian Constitution (Oxford University Press, 2017) 1053. See also Joanna Harrington, "Interpreting the Charter," in Oliver, Macklem \& Des Rosiers, supra note 37, 621; Stéphane Beaulac, "Constitutional Interpretation: On Issues of Ontology and of Interlegality," in Oliver, Macklem \& Des Rosiers, supra note 37, 867. Even the text most associated with the argument that the legislature holds primary responsibility for specifying the content of rights recognizes that the judiciary currently possesses that role in Canada and argues this is a mistake. See Grégoire Webber et al, Legislated Rights: Securing Human Rights through Legislation (Cambridge University Press, 2018).

38. The extent to which judges should draw on ethical and political concerns in interpretation is, of course, central in ongoing philosophical and practical debates. For an introduction, see "Constitutionalism" (last updated 20 December 2017), online: Stanford Encyclopedia of Philosophy <seop.illc.uva.nl/entries/constitutionalism>. 
One challenge posits that the idea of "positive rights" is confused. Critics begin by identifying basic features of "rights," like a rights holder who possesses an entitlement with specifiable, determinate content and either a correlative duty possessed by a specifiable duty bearer ${ }^{39}$ or justifiable enforcement of the right. ${ }^{40}$ A plausible defence of "positive rights" should identify these features and explain both why and when the rights bearer-duty bearer relationship holds. Critics argue that no plausible account can or does exist. ${ }^{41}$

Jurisprudential recognition of positive rights should address the concerns animating this conceptual challenge. Even if proponents are right to suggest that "positive rights" (which possess all the claimed necessary features above) clearly exist in the law of many states in ways that permit enforcement, ${ }^{42}$ or that conceptual confusion with "positive rights" stems from a false distinction between "positive" and "negative" rights (as all rights require some positive action), ${ }^{43}$ theoretical problems with positive rights remain. Those theoretical problems can themselves create further practical problems with recognizing positive rights. All relevant stakeholders, including those who deny that the positive-negative rights distinction is coherent, accept that rights entail correlative duties. ${ }^{44}$ A defence of positive rights should include an action-guiding means of identifying and justifying the duties and distinguishing between specific entitlements that "rights

39. See Jeremy Waldron, ed, Theories of Rights (Oxford University Press, 1984) at 8 (discussing the framework addressed by Wesley Newcomb Hohfeld. Waldron cites versions of Hohfeld's articles which have been revised since their publication in the Yale Law Journal. The original versions of the texts are cited here). See Wesley Newcomb Hohfeld, "Some Fundamental Legal Conceptions as Applied in Judicial Reasoning” (1913) 23 Yale LJ 16; Wesley Newcomb Hohfeld "Fundamental Legal Conceptions as Applied in Judicial Reasoning" (1917) 26 Yale LJ 710.

40. Indeed, even proponents of positive rights suggest that some weak form of enforcement in the form of public moral condemnation should be possible. See Michael Da Silva, "Correlativity and the Case Against a Common Presumption About the Structure of Rights" (2020) 54 J Value Inquiry 289 [Da Silva, "Case"].

41. See e.g. the classic discussions of this point in Charles Fried, "Positive Rights" in Right and Wrong (Harvard University Press, 1978) 108. For a sharp and influential version of this criticism, see Onora O’Neill, Towards Justice and Virtue (Cambridge University Press, 1996) at 128-36; Onora O’Neill, “The Dark Side of Human Rights” (2005) 81 Intl Affairs 427.

42. See e.g. Jeff King, Judging Social Rights (Cambridge University Press, 2012) [King, Social].

43. See e.g. Henry Shue, Basic Rights: Subsistence, Affluence, and U.S. Foreign Policy, 2nd ed (Princeton University Press, 1996) at 36-40; Stephen Holmes \& Cass R Sunstein, The Costs of Rights (WW Norton \& Company, 1999).

44. Da Silva, "Case," supra note 40. In addition, see e.g. Elizabeth Ashford, "The Duties Imposed by the Human Right to Basic Necessities" in Thomas Pogge, ed, Freedom from Poverty as a Human Right: Who Owes What to the Very Poor? (Oxford University Press, 2007) 183. The legal sources in note 14 likewise agree on this. 
bearers" possess and merely purported claims. ${ }^{45}$ While Canadian constitutional rights have clear duty bearers as a matter of law, this does not negate the need to explain why and when Canadian governments owe specified duties to fulfill positive "rights." ${ }^{36}$ Any relevant moral reasons should also explain why any legal right should be enforced. Finding one positive right that meets the criteria can establish that "positive rights" are not conceptually confused, but all judicially recognized rights should be able to fulfill the criteria.

These issues can overlap with further institutional concerns. Canadian courts that recognize positive rights will face charges that they have overstepped their judicial role. Executive and legislative decision makers are, in this view, uniquely epistemically positioned to deal with relevant social concerns and democratically authorized to make relevant decisions. ${ }^{47}$ The drafters of the constitution chose not to explicitly recognize positive rights, potentially further undermining the legitimacy of positive rights. ${ }^{48}$ Given these priors, critics will likely charge, judicial recognition of positive rights is democratically or constitutionally illegitimate.

Advocates for positive rights thus owe a story of why judges can recognize the rights. Even the most plausible available arguments for the constitutional recognition of positive rights face challenges. For example, judicial review of social policy for compliance with constitutional rights is part of the judicial role, and there are good faith arguments one can use to construct "positive" content out of existing rights. ${ }^{49}$ For another example, judicial review may also be functionally unavoidable. If judicial review of health care policy is unavoidable post-Chaoulli, the question becomes what kind of review the SCC will take. ${ }^{50}$ Yet neither

45. While scholars debate whether there can be multiple duty bearers or options for fulfilling duties, the otherwise radically different sources above (in e.g., notes 39-44) agree that one must identify a specified domain of duty bearers and duties.

46. The duty bearer is clear in the Charter, though who qualifies as "government" is complex.

47. Webber et al, supra note 37. This text outlines many of the most compelling arguments likely to be adduced. Each co-author has, of course, also written extensively on judicial competence in ways that challenge claims about the judiciary's epistemic competence and democratic authority to address complex policy determinations. See e.g. Geoffrey Sigalet, Grégoire Webber \& Rosalind Dixon, eds, Constitutional Dialogue: Rights, Democracy, Institutions (Cambridge University Press, 2019); Paul Yowell, Constitutional Rights and Constitutional Design (Hart Publishing, 2018).

48. This is important where even "purposive" interpretation is supposed to be responsive to the text of the constitution and its context of distribution. See e.g. Rv Big M Drug Mart Ltd, [1985] 1 SCR 295 at para 117 [Big M].

49. But recall the contrary position. See e.g. Webber et al, supra note 37.

50. Jackman, "Chaoulli," supra note 9 at 40 (also advocating "a reading of the Charter that reinforces rather than undermines the publicly funded system and the domestic and international human rights principles it reflects"). 
example explains which rights should be recognized. Even if, for instance, there is a positive international legal or moral right to health care, questions remain about whether and how courts should realize it. Adopting international standards is worrisome where courts cannot directly incorporate international law into domestic law. ${ }^{51}$ Appeals to moral concerns will raise more legitimacy concerns. Competing accounts of what any positive right to health care requires in international law or moral theory create further concerns. ${ }^{52}$ Canadian judges are not well placed for, or institutionally charged with, evaluating competing moral or international jurisprudential theories. ${ }^{53}$ Guidance on which rights to recognize and when to recognize them remains necessary.

These concerns overlap with jurisprudential issues of recognition. The lack of textual support for positive rights is just one jurisprudential concern. ${ }^{54}$ Worries about judges overstepping their role when acting in social policy also apply here. ${ }^{55}$ Even if courts can recognize positive constitutional rights, some strong moral reasons should explain why courts should recognize them. The purported reasons for recognition that I have outlined raise questions about whether courts can choose between competing models. Yet some reasons to recognize positive rights may not justify positive constitutional rights. To wit, constitutional health rights

51. Canada remains a "dualist" State, in the sense discussed in Janne E Nijman \& André Nollkaemper, eds, New Perspectives on the Divide Between National and International Law (Oxford University Press, 2007), insofar as international law is not directly imported into domestic law (with the possible exception of customary international law after Nevsun Resources Ltd v Araya). See Nevsun Resources Ltd v Araya, 2020 SCC 5. Even stating that international law can be used to interpret the constitution does not make international law directly binding. One still needs clear domestic law to interpret it. See Baker v Canada (Minister of Citizenship and Immigration), [1999] 2 SCR 817; R v Sharpe, 2001 SCC 2; $R v$ Hape, 2007 SCC 26; Ontario (AG) v Fraser, 2011 SCC 20.

52. Compare competing models cited above and below.

53. On the competing theories, compare e.g. Lisa Forman et al, "Conceptualising minimum core obligations under the right to health: How should we define and implement the 'morality of the depths" (2016) 20 Intl JHR 531; Michael Da Silva "The International Right to Health Care: A Legal and Moral Defense" (2018) 39 Mich J Intl L 343 [Da Silva, "International"]. For another strong overview of competing views and defense of an alternative, see Katharine G Young, Constituting Economic and Social Rights (Oxford University Press, 2012).

54. See Charter, supra note 13. Cf the texts of the constitutions discussed in Evan Rosevear, Ran Hirschl \& Courtney Jung, "Justiciable and Aspirational Economic and Social Rights in National Constitutions" in Katharine G Young, ed, The Future of Economic and Social Rights (Cambridge University Press, 2019) 37.

55. Recall common critiques of cases like Bedford, supra note 15; Carter, supra note 17; Chaoulli, supra note 22; Morgentaler, supra note 24; Insite, supra note 24. Criticisms of the judiciary in these cases cross the political spectrum. CfFlood \& Thomas, Two-Tier, supra note 9; Sigalet, Webber \& Dixon, supra note 47. 
are often promoted due to their ability to resolve resource-allocation disputes, but proponents suggest that they need not do so to be valuable. ${ }^{56}$ While they can secure better access to health care, ${ }^{57}$ they can also serve other functions without directly contributing to that end. ${ }^{58}$ They can, for instance, foster creative problem solving of technical problems or health care reform more generally. ${ }^{59}$ Yet these goals do not rely on constitutionalization. "The right to health" can have value in non-justiciable policies. ${ }^{60}$ Constitutionalization is not strictly necessary for realizing international or non-legal health rights.

Finally, common pitfalls in other states provide still other reasons to be cautious and plausibly explain past judicial reluctance to recognize positive rights. These include concerns that positive rights are insufficiently precise, creating potentially overbroad rights that can radically reorient social spending and leave governments unable to realize all entitlements, or concerns that they will be "co-opted" to further the priorities of those who can afford judicial remedies that are realized elsewhere. ${ }^{61}$ Advocates should explain how Canadian recognition of positive rights will address these concerns.

\section{PRECEDENT AS A GUIDE TO APPROPRIATE RECOGNITION OF POSITIVE RIGHTS}

The SCC has, again, provided unfortunately little guidance on the extent to which any account of positive rights must address the issues that I outlined in Part II, above. I propose that the SCC's test for precedent is an institutionally

56. Nicole Hassoun, "The Human Right to Health: A Defense" (2020) 51 J Social

Philosophy 166 [Hassoun, "Defense"]. Hassoun discusses non-constitutional—and even non-governmental-approaches in greater detail in Global Health Impact: Extending Access to Essential Medicines (Oxford University Press, 2020) [Hassoun, Global].

57. Hassoun, "Defense," supra note 56 at 165.

58. Hassoun, Global, supra note 56 at 8. See also S Katrina Perehudoff, Nikita V Alexandrov \& Hans V Hogerzeil, "The Right to Health as the Basis for Universal Health Coverage: A Cross-National Analysis of National Medicines Policies of 71 Countries" (2019) 14 PLOS ONE.

59. Ibid.

60. Hassoun, Global, supra note 56 at 11.

61. See e.g. Florian F Hoffmann \& Fernando RNM Bentes, "Accountability for Social and Economic Rights in Brazil" in Varun Gauri \& Daniel M Brinks, eds, Courting Social Justice: Judicial Enforcement of Social and Economic Rights in the Developing World (Cambridge University Press, 2008), 100; Alicia Ely Yamin \& Siri Gloppen, eds, Litigating Health Rights: Can Courts Bring More Justice to Health? (Harvard University Press, 2011), ch 3-6, 11. For an excellent, more recent update, see Alicia Ely Yamin, "The Right to Health in Latin America: The Challenges of Constructing Fair Limits” (2019) 40 U Pa J Intl L 695. 
appropriate (if imperfect) guide to analyzing the relevant concerns. There is, of course, a sense in which recognition of positive rights would not constitute going against past precedent. If the "door" is "ajar," recognition would not formally contradict a statement that recognition is impossible. ${ }^{62}$ Moreover, some of the issues in Part II go to extrajudicial measures that have escaped judicial scrutiny or questions about whether courts can adjudicate positive rights claims at all. ${ }^{63}$ One may accordingly charge that viewing this solely as a matter of precedent is mistaken or artificial. A stronger argument could hold that there is "no law" here. ${ }^{64}$ Courts can always use past "precedents" to construct arguments for new conclusions. ${ }^{65}$ They appear unconstrained by legal rules. They should be constrained by the constitutional text, but those constraints are non-dispositive of possible positive rights recognition. The lack of guidance on when it would be appropriate to recognize positive rights is, in this view, a function of courts' broad discretion regarding when they can go against past decisions, and their lack of a clear mandate to recognize positive rights from any perspective. This could entail that recognition is always illegitimate absent a legal mandate, such as one that could be provided in an amendment. These criticisms should not be taken lightly.

Applying the precedent test is nonetheless useful: It aids understanding of how the SCC bound itself to view positive rights claims and provides data that one can use to examine persistent issues therewith. Concerns that recognition of positive rights would not formally go against past precedent or that courts lack a legal mandate to recognize positive rights are well taken. Yet whether courts can recognize positive rights is partly what is at issue in this debate. An external standard for evaluating judicial decisions that one can use in a broader analysis of judicial competence, if not full judicial authority, in the adjudication of positive rights remains desirable. Those who are concerned about courts simply changing their minds whenever they feel like it, unconstrained by legal rules, should likewise desire standards for assessing changes. Approaching these issues from the perspective of precedent at least provides insight into how courts could justifiably approach them, according to their own lights, and provides one with a clear test for evaluating changes that maps some central concerns. These benefits favour my approach, absent clear guidance on when courts could or should recognize

62. Thank you again to an audience Western University Faculty of Law and an anonymous review for raising the objections in this paragraph. These points were raised and stressed by multiple audience members at Western.

63. Ibid.

64. Ibid. Western University's Randal Graham raised the particular "no law" objection.

65. While this point arose from the audience at Western University Faculty of Law, it was clearest in comments by the aforementioned anonymous reviewer. See supra note 62 . 
positive rights. Applying the test to the issue of the recognition of positive rights then provides insights into several persistent debates.

I use the precedent test to analyze the legitimacy of future recognition of positive rights, not to predict when recognition may take place. Some may argue that the "real" considerations motivating change will be external to the norms here, and precedential concerns will be used as "cover" for a change in preferences. ${ }^{66} \mathrm{Yet}$ the considerations that best predict change from a preference-based perspective could vary across cases, limiting this concern, and the question of whether the law of precedent provides persuasive cover remains important even on this deflationary account. My interest is in that broader argumentative persuasiveness and legitimacy.

With this in mind, we can turn to the modern test for overruling precedent as introduced in Bedford and developed in Carter v. Canada (Attorney General) ("Carter"). It holds that courts can go against past precedent when a new legal issue arises due to:

1. non-consideration of available legal arguments in prior cases; or

2. changes in legal doctrine, such that:

a. aspects of a prior law were not addressed; or

b. new circumstances or evidence arise, including new adjudicative facts (viz. differences in the case itself) and new "legislative and social facts" regarding the context of the law's application (like changes in transnational law and expert or public opinion on relevant issues). ${ }^{67}$

66. See e.g. Carter, supra note 17. Carter is a health law case that some recognize as creating a positive entitlement to assisted death but is better understood as ensuring a negative right not to face criminal sanction for participating in that health care procedure. It featured a claimant who suffered from the same illness and made the same claim as the lead claimant in the case it overturned. See Rodriguez, supra note 17. The outcome may be best explained by changes in judicial preferences about assisted death or judicial sympathy (though sympathy has been insufficient in other cases. See T(A) (Litigation Guardian of) v Ontario Health Insurance Plan (General Manager), 2010 ONSC 2398.

67. See Bedford, note 15; Carter, supra note 17. The test was subsequently restated in $R v$ Comeau, 2018 SCC 15. This case added only that the threshold for change is high and suggests that "profound change in social circumstances" is needed to justify a change (ibid at paras 34-36). It cites Bedford for authority. Bedford and Carter provide the specific examples of necessary changes outlined here. While one could argue that earlier cases provide kernels of the same statement, Bedford and Carter formalize past statements and add additional content. At a minimum, they provide more guidance for what is necessary to allow such changes than did previous decisions. This clarification alone warrants application of the test to present circumstances. This is so regardless of whether the test here is "new." I accordingly do not spend substantial time addressing the question of whether and how the Bedford-Carter 
Bedford identified the need for a new legal issue in order to go against precedent and established that changes in the law as a result of new circumstances or evidence are exemplary of new legal issues. ${ }^{68}$ The final SCC judgment noted that complete criminal prohibitions on "common bawdy houses" and "living on the avails" of prostitution created a risk for sex workers by making them unable to hire bodyguards or screen potential clients for violent propensities. ${ }^{69}$ It upheld the trial-level judgment that this violated section 7, overturning SCC precedent. This required clarification regarding when going against precedent was appropriate. The SCC noted that trial judges can go against past precedent when new legal issues arise (due to arguments based on Charter provisions not considered in earlier cases or on new legal developments) or there is a change in circumstances or evidence that shifts the terms of the debate. ${ }^{70}$ The SCC offered little explanation of when it could go against its own precedent, but statements justifying the test on the basis of the need for "finality" and "stability," as well as the necessity of being able to go against past precedent in at least some circumstances to perform their role, apply equally to the SCC. ${ }^{71}$ We can thus also view the holding as guidance for when it is appropriate for the SCC to go against its own precedent. Indeed, the SCC in Bedford went against its precedent from the Prostitution Reference partly due to new legal issues therein. ${ }^{72}$ The SCC thus plausibly needs to strike the same "balance" between competing interests when addressing its own precedents.

Bedford also identified when new issues may arise. Non-consideration of a prior legal argument and changes in legal doctrine were both legal changes that could warrant overturning past precedent. Revisiting a section 7 argument was appropriate in Bedford because the earlier case did not address a security of the person claim and because the principles of fundamental justice of arbitrariness, overbreadth, and grossly disproportionate effects did not exist when the prior case was decided; this change in legal facts created new legal issues. ${ }^{73}$ Discussion

test departs from prior cases here.

68. Bedford, supra note 15.

69. Ibid at e.g. paras 64-72, 148-50, 164. The section 2(b) argument also came up again but was not addressed in full since the case was already resolved on section 7 grounds (ibid at para 160). Such an argument would also falter due to the precedent issue. The 2(b) issues had been dealt with already in the Prostitution Reference and there were no changes in the factual circumstances that would have warranted overturning the section 2(b) decision.

70. Ibid at paras 43-44.

71. Ibid at para 44 .

72. Ibid at paras 43-45.

73. Ibid. 
of "the evidence of affiants and experts, and documentary evidence in the form of studies, reports of expert panels and Parliamentary records" as proper evidence in Bedford also helpfully specified the kinds of evidentiary matters that could lead to different outcomes, though discussion thereof primarily concerned whether deference was owed to the lower courts, not the evidence's impact on the ultimate case outcome. ${ }^{74}$

Carter then provided greater detail on the kinds of changing circumstances and evidence, beyond the adjudicative facts of the case at bar, that could warrant going against past precedent. The adjudicative facts of Carter and the case it overturned, Rodriguez v. British Columbia (Attorney General) ("Rodriguez"), were nearly identical. The relevant changes concerned legislative and social facts. The legal changes were the same as those identified in Bedford, with the "new" principles barring overbreadth and grossly disproportional effects highlighted as key to overturning precedent. ${ }^{75}$ This reinforced the legal changes that justify overturning precedent in a familiar way.

Carter's main contribution to the jurisprudence on when it is appropriate to go against past precedent was its application of the legislative and social facts branch of the precedent test. The Court in Carter detailed why changes in legislative and social facts also warranted reconsideration and a different outcome, and thereby identified the kind of changes that could warrant reconsideration of past precedent. ${ }^{76}$ It appealed to transnational law, expert opinion of the issues relevant to the case, and public opinion of the same to justify its change. ${ }^{77}$ Most famously, the Court identified three issues key to Rodriguez that were no longer supported by the evidence: "the widespread acceptance of a moral or ethical distinction between passive and active euthanasia"; "the lack of any "halfway measure' that could protect the vulnerable"; and "the 'substantial consensus' in Western countries that a blanket prohibition is necessary to protect against the slippery slope.... The record...contained evidence that, if accepted, was capable of undermining each of these conclusions." ${ }^{78}$

The majority judgment affirmed trial-level findings that justified a change on the basis of transnational law and changes in expert and lay opinion. Perhaps most

74. Ibid at para 54. Notably, the list here also includes "the personal evidence of the applicants," which could specify a factual change but may not itself produce a new legal argument or change in legal doctrine.

75. See e.g. Carter, supra note 17 at para 46.

76. Ibid at paras 44-47 (with facts also discussed at paras 7-10).

77. Ibid. See also ibid at paras 110-20 (regarding the discussion of the minimal impairment change).

78. Ibid at para 47 [citations omitted]. 
importantly for present purposes, it looked to transnational law to demonstrate that the decriminalization of assisted death in some European and American states showed that it did not invariably lead to the euthanizing of the vulnerable. It noted examples of measures short of prohibition that protect the vulnerable. ${ }^{79}$ This possibility was (apparently) not clear when Rodriguez was decided, but changes in the transnational legal record undermined previous arguments that a criminal prohibition accords with the principles of fundamental justice and section 1 of the Charter. Foreign legal facts served as social facts. Legalization in the Netherlands, Belgium, Luxembourg, Switzerland, three American states, and Colombia demonstrated that the legalization of assisted death would not necessarily produce abuse (or the substantial probability thereof) or have a disproportionate impact on the socially vulnerable. ${ }^{80}$

Changes in expert and lay opinion also motivated Carter. Echoing Bedford, the trial judgment looked to a Royal Society of Canada report and a Quebec National Assembly report to demonstrate a change in expert opinion, and to public opinion documents to demonstrate relevant changes in circumstances: Academic and public support for the morality of assisted death undermines the constitutionality of criminalization. ${ }^{81}$ On the basis of these documents, the SCC also noted that there is no longer consensus on the value of the killing-letting die distinction that once grounded a case for prohibition or for the necessity of blanket prohibitions. ${ }^{82}$ Rodriguez was partly based on the need to have institutions reflect public morality, so these changes matter. ${ }^{83}$

79. The court accepted the trial judge's factual findings on this matter. See ibid at paras 25, 47.

80. Ibid at paras $8,25,47$. Some scholars challenge the data on the foreign experience used by the SCC in this case and the applicability of this data in the Canadian context. See e.g. Trudo Lemmens, "The Conflict Between Open-ended Access to Physician-Assisted Dying and The Protection of the Vulnerable: Lessons from Belgium's Euthanasia Regime in the Post-Carter Era" [Lemmens, "Conflict"] in Catherine Régis, Lara Khoury \& Robert Kouri, eds, Les grands conflits en droit de la santé (Yvon Blais, 2016) 261. The perceived threat of a euthanasia free-for-all has not been realized in Canada, but more Canadians were choosing assisted death in the years immediately following its limited non-criminality than before. Health Canada, Fourth Interim Report on Medical Assistance in Dying in Canada (Health Canada, 2019).

81. Carter, supra note 17 at paras 7, 47 .

82. Ibid at paras 23-24, 47.

83. See especially Rodriguez, supra note 17 at para 47 . There is also no consensus on the opposite(s), which the majority seemed to want in parts of Rodriguez, but there are changes. Given the application of this test in Carter, and lack of consensus on the opposite view there, one does not appear to need a shift from one consensus to another to warrant changes in legal outcomes. Consensus likely was not possible circa Rodriguez. 
Neither Bedford nor Carter specified the quanta of changes in legislative and social facts that could warrant doctrinal change, but application of the lemma of the precedent test in Carter suggests that there should be a sufficient number of changes to undermine concerns grounding a section 1-style argument for limitations on rights. If changes undermine the case that a given limitation accords with section 1 by, for instance, explaining how a proposed limitation is no longer necessary to fulfill a valid government objective, this provides reason to go against past precedent (all else being equal). I suspect that changes in public opinion alone will rarely justify going against past precedent, but the SCC clearly holds that public opinion can at least be indicative of relevant issues and can undermine some section 1 claims, so consideration thereof remains important.

\section{APPLYING THE TEST}

The lag in cases addressing positive rights claims at the SCC spanned many substantial changes in law, politics, and social science that could justify recognition of positive rights under (at minimum) sections 7, 12, and 15, despite past precedent suggesting that Charter rights lack positive components. ${ }^{84}$ Changes on several components of the precedent test likely permit recognition of positive rights under that test, but applying it highlights why recognition may be unwise, all-things-considered, and provides guidance on how judges may avoid some serious problems with such recognition.

\section{A. NON-CONSIDERATION OF AVAILABLE LEGAL ARGUMENTS IN PRIOR CASES}

The first branch of the precedent test does not contribute much to a case for the recognition of positive Charter rights. Consideration of new legal arguments is a

84. The dissent in Gosselin identifies "rights to vote (s. 3), to trial within a reasonable time (s. 11(b)), to be presumed innocent (s. 11(d)), to trial by jury in certain cases $(s .11(f)$ ), to an interpreter in penal proceedings (s. 14), and minority language education rights (s. 23)" as examples of rights that "impose positive obligations of performance on the state and are therefore best viewed as positive rights (at least in part)." Supra note 19 at para 320. It goes on to suggest that section 7, too, should have positive components. Ibid at 357. Notwithstanding this history, sections 7, 12, and 15 of the Charter are not currently recognized as having positive components. Whether the other rights noted in the Gosselin dissent are "positive" rights is beyond the scope of this work. If so, there is still a need to determine whether past precedent on the other rights can be reconsidered and overturned, but the existence of those other rights was already clear at the time of Gosselin, so recognition of their positive components cannot warrant reconsideration or change. 
highly factual determination, focusing on the adjudicative context of actual cases, so there is little that this branch could even potentially contribute to any general understanding of whether a legal doctrine should be overturned. If litigants can source arguments for positive rights in parts of section 7 or 15 not considered in prior cases, this could warrant overturning past precedent, but that depends on the historical record of court challenges and the facts of new cases. The novelty of a section 12 argument suggests a new path towards future recognition of positive Charter rights, but this does little to establish that sections 7 and 15 should be read in a new light. Eventual recognition of a positive element of section 12, while unlikely, would support an argument that there are positive rights under the Charter and bolster the case for recognizing positive elements of other rights.

\section{B. CHANGES IN LEGAL DOCTRINE SUCH THAT ASPECTS OF A PRIOR LAW WERE NOT ADDRESSED}

New developments in the law may open the "door" to the reconsideration of past precedents in which positive rights were denied. Here too, the factual circumstances of whether parts of new tests will lead to different outcomes will be case-specific. But doctrinal changes suggest that possible positive rights claims have not been directly addressed under all relevant tests for compliance.

Doctrine-based arguments under section 7 are intriguing, though more complicated than they appear at first glance. The development of new branches of the principles of fundamental justice test that justified changes in Bedford and Carter could potentially warrant reconsideration of past negative-rights-denying section 7 claims. ${ }^{85}$ Positive rights claims have not been directly addressed in cases where the modern principles of fundamental justice have been recognized. The modern principles of fundamental justice test was available at the time of Carter, but that case lacks explicit statements on the recognition of positive rights and so cannot stand for the proposition that arguments for positive rights were already addressed under the present section 7 test. $^{86}$ If this branch requires only that the past claim was heard under current doctrinal tests, one could argue that this applies to positive rights claims under the modern test for section 7 compliance.

Closer scrutiny complicates the picture but may not defeat the case for recognition of positive rights under section 7 . The principles of fundamental

85. Both Carter, supra note 17 and Bedford, supra note 15 highlight the articulation of new principles of fundamental justice, most clearly formalized in Insite, supra note 24, as justifying a change. Those principles and the formalization thereof were not yet operative at the time of Gosselin. See supra note 19.

86. Carter, supra note 17. 
justice test is, of course, only triggered if the rights to life, liberty, or security of the person are engaged. Changes in the fundamental principles cannot establish that there should be a change in their triggering conditions, at least on a strict understanding of what it means for a claim not to have been heard under a past test.

Yet a claim not being heard under a past test admits of multiple interpretations. It is most plausibly read as requiring that the particular rights claim or principle at issue has not been addressed previously, so this concern is real. One could point to some small changes in "life, liberty, and security of the person" doctrine to ground a new case for recognition, but these arguments would be more difficult. Luckily for those who argue for positive rights, other interpretations of this lemma remain possible.

One could, for instance, argue that section 7 should be understood as a single constitutional provision, and changes in the principles of fundamental justice suffice to change the entire section 7 test. This would establish a "new" claim for recognizing positive rights but may strain credulity as an interpretation. An alternative interpretation under which "life, liberty, and security of the person" must be understood in light of "the principles of fundamental justice" - such that the possible content of the former should be interpreted in light of the latter-is more compelling, though not without its own controversies. The new principles of fundamental justice may provide measures for ensuring that recognizing a positive scope to the rights to life, liberty, and security of the person does not become too demanding or imprecise. The tests for the new principles provide clear criteria for ensuring that rights recognition remains just. The kinds of "slippery slope" arguments that hampered past recognition are thereby potentially blunted, at least warranting reconsideration of past claims. This interpretation, too, may face charges that it misunderstands the relationship between the parts of section 7 or the relevant lemma of the test, but there is some doctrinal support for the view, and the relevant rights likely should be understood in light of the principles and, indeed, of other potential safeguards against rights "inflation" or misuse. ${ }^{87}$ At the very least, the possibility of a new claimed positive right under section 7 could combine with the new principles of fundamental justice to warrant recognition under this branch. This could not establish the "freestanding right to healthcare" rejected in Chaoulli but could establish other social rights. Good-faith arguments under this lemma could still support section 7-based positive claims.

87. Ibid. For the more standard reading, with some supplements of the basic case law and interpretative provisions, see classic textbooks like Peter W Hogg, "Fundamental Justice" in Constitutional Law of Canada, 5th ed (Carswell, 2007). 
Changes to section 15 doctrine can, in turn, more clearly help justify courts in departing from established precedent on the possibility of using the provision to help realize positive rights, like the right to health care. The test for section 15 compliance changed several times post-Auton. ${ }^{88}$ Positive rights claims have not yet been heard under the modern test. ${ }^{89}$ More narrowly, but still importantly, the need to establish a clear comparator class that was given the benefit(s) sought by the litigant in a given case historically served as a barrier to establishing differential treatment and a denial of benefits that could ground a section 15 claim. ${ }^{90}$ The need for a mirror group who received the benefits was often difficult to establish in the past. But the SCC now allows more flexibility in the identification of comparator classes and does not require a clear mirror. ${ }^{91}$ These are sufficient changes to justify examination of other doctrines that were developed in tandem with the now replaced section 15 requirements and tests. Recently expanded recognition of "adverse effects discrimination" may further justify change. ${ }^{92}$

Finally, more recent (admittedly lower-level) case law on the cruel and unusual treatment branch of section 12 constitutes a change in the legal architecture that has not been considered in past positive rights cases. Despite the SCC's recent development of this branch of section $12,{ }^{93}$ case law remains minimal. The few cases where the SCC discusses a "treatment" component of section 12 address "treatments or punishments," not "treatment(s)" simpliciter, leaving the precise nature of this potential branch of section 12 unclear; the cases also address only negative rights. ${ }^{94}$ Binding higher-court precedent on the treatment branch and potential positive rights underneath it remains lacking. Yet Refugee Care plausibly argued that freedom from cruel and unusual treatment requires positive action on the part of government, including the ongoing provision of specific goods. ${ }^{95}$ Where the prior non-pleading of a legal claim now lets courts overturn past precedent on similar facts, the SCC can recognize a positive right under section 12 without violating precedent.

88. Auton, supra note 31 was decided under the test in Law $v$ Canada (Minister of Employment and Immigration), [1999] 1 SCR 497. New tests have since appeared in $R v$ Kapp, 2008 SCC 41 [Kapp]; Withler v Canada (AG), 2011 SCC 12 [Withler]; Quebec (AG) v A, 2013 SCC 5 [Quebec v A]; Kahkewistahaw First Nation v Taypotat, 2015 SCC 30 [Taypotat]. Fraser v Canada (AG), can also be read as providing a new test. See 2020 SCC 28 [Fraser].

89. Quebec v A, supra note 88; Taypotat, supra note 88. Or, perhaps, see Fraser, supra note 88.

90. As noted above, this was even a problem in Gosselin, supra note 19 at para $236 \mathrm{ff}$.

91. This has been so since Withler, supra note 88 .

92. Fraser, supra note 88.

93. See e.g. $R v$ Nur, 2015 SCC 15; Rv Jordan, 2016 SCC 27.

94. See e.g. Suresh $v$ Canada (Minister of Citizenship and Immigration), 2002 SCC 1.

95. Refugee Care, supra note 28. 


\section{CHANGES IN CIRCUMSTANCES OR EVIDENCE}

\section{ADJUDICATIVE FACTS}

As with non-consideration of available legal arguments in prior cases, this aspect of the test is dependent on the facts of cases and so cannot be comprehensively assessed in the abstract. Changes in adjudicative facts may not be necessary to overturn past precedent if other statements here are correct. The adjudicative facts underlying the claims in Carter and Rodriguez were nearly identical. ${ }^{96}$ Changes in law, legislative facts, and social facts suffice. Yet even if changes in adjudicative facts are not necessary to overturn past practice, the adjudicative facts of Gosselin, which established that section 7 does not contain a positive component, were remarkably weak. That factual weakness should make it easier to overturn past precedent here than in other contexts.

It may be that the door to recognizing positive rights was ajar in Gosselin only because the claimant failed to establish that her right was violated. Gosselin was denied full social security benefits because she was of working age and failed to complete training or remedial education courses that would plausibly assist her in finding work. She brought a claim on behalf of a "class" of persons of a government-mandated working age who did not participate in the specified activities but otherwise qualified for social security benefits. The holding that the relevant law did not violate the rights of those below the age threshold who did not complete the courses relied heavily on Gosselin's failure to adduce evidence that the denial of benefits in her case undermined her specific section 7 or 15 rights or those of similarly situated persons. The majority emphasized that her claim was based primarily on her own testimony and evidence that Gosselin tried the programs but could not finish them; no other person spoke in favour of the purported "class." ${ }^{\text {"97 }}$ The majority frequently highlighted evidentiary problems in Gosselin's case. ${ }^{98}$ I suspect that some who use Gosselin for the proposition that the time for positive rights has not yet come ignore Gosselin's poor evidentiary case. Building on the logic of Gosselin with more reasonable facts could introduce positive rights. ${ }^{99}$ But my argument about past precedent does not rely on this contentious claim alone.

96. See my commentary, supra note 66.

97. Gosselin, supra note 19 at para 8.

98. Gosselin, supra note 19.

99. I also note this point in a footnote in Da Silva, Pluralist, supra note 14, ch 8. 


\section{LEGISLATIVE AND SOCIAL FACTS}

There are also likely enough changes in legislative and social facts to warrant recognition of positive elements of at least some Charter rights.

\section{TRANSNATIONAL LAW}

Perhaps most importantly, foreign legal experiences now demonstrate that the concerns animating the SCC's reluctance to recognize positive rights under the Charter are not necessary consequences of recognition. Just as foreign law once undermined the claim that assisted death necessarily produces a slippery slope towards active euthanasia in Carter, foreign law now undermines the claim that recognizing positive rights necessarily produces a slippery slope towards judicial overreach or gross misallocation of public funds. ${ }^{100}$ Carter established that foreign legal experiences can count as evidence of changing social and legal facts in Canada. ${ }^{101}$ Positive rights are now widely recognized in other jurisdictions. Increased recognition of social rights elsewhere could itself be a change in social facts that justifies changes. ${ }^{102}$ Increased understanding of foreign experiences further establishes that past judicial concerns limiting recognition need not apply in Canada-even if these concerns do not establish that such recognition is, all-things-considered, desirable in foreign jurisdictions, let alone in a country like Canada with its own issues.

The record on positive constitutional rights recognition from a public policy perspective is mixed. This raises questions about whether recognition is, all-things-considered, desirable, but need not undermine the legitimacy of recognition under the precedent test. There is likely enough evidence to undermine at least some concerns motivating past precedent on positive rights recognition. Surveying this vast literature requires its own work, ${ }^{103}$ but some representative points help to establish this modest claim. Positive rights are now recognized in a majority of world constitutions. ${ }^{104}$ Rights to education and health care are the most common ones. ${ }^{105}$ Those rights in particular are

100. I am generally skeptical of the existence of slippery slopes. But the judicial point here can be read conditionally: Even if slippery slopes exist, recognition of positive rights need not entail potentially problematic slippery slopes.

101. Carter, supra note 17.

102. Rosevear, Hirschl \& Jung, supra note 54. See also Young, supra note 54; Langford, supra note 14; Gauri \& Brinks, supra note 61; Yamin \& Gloppen, supra note 61.

103. I spend a whole book on health care alone. See Da Silva, Pluralist, supra note 14.

104. See the sources in supra note 102.

105. Ibid. 
often justiciable and not merely aspirational. ${ }^{106}$ They most often appear in less developed states, so one could argue that they are meant to "fast-track" social success in developing states. ${ }^{107}$ Their record of doing so is mixed. ${ }^{108} \mathrm{~A}$ right to health care can, for instance, be a powerful tool for increasing access to health care. ${ }^{109}$ In Latin American states without stare decisis, "health rights" that were not subject to limitation clauses led to overlitigation, overspending on goods that litigants sought, and co-option whereby spending on luxury goods came at the expense of spending on goods needed by the wider population and more vulnerable groups who could not access the courts. ${ }^{110}$ Yet experiences in India and other common law countries outside Latin America demonstrate that expanding a right to life to include health care entitlements need not lead to calamity. ${ }^{11}$ While the prevalence of some rights was clear prior to some past cases, ${ }^{112}$ much

106. Ibid.

107. This is a theme in parts of the analysis of the right to health. See Flood $\&$ Gross, supra note 14.

108. See ibid. See supra notes 61, 102. See further details below.

109. Minister of Health and Another $v$ Treatment Action Campaign and Others, 2002 (5) SA 721 (CC) (S Afr). This case is a classic example, though the value of South Africa's right to health care services as a tool for increasing access to health care or equity remains debatable. $C f$ Lisa Forman, "Justice and Justiciability: Advancing Solidarity and Justice through South African's right to Health Jurisprudence" (2008) 27 J Med \& L 661; Lisa Forman \& Jerome Amir Singh, "The Role of Rights and Litigation in Assuring More Equitable Access to Health Care in South Africa" in Flood \& Gross, supra note 14, 288; Sandra Liebenberg, "The Participatory Democratic Turn in South Africa's Social Rights Jurisprudence" in Young, supra note 54, 187; Ottar Maestad, Lise Rakner \& Octavio L Motta Ferraz, "Assessing the Impact of Health Rights Litigation: A Comparative Analysis of Argentina, Brazil, Colombia, Costa Rica, India, and South Africa" in Yamin \& Gloppen, supra note 61, 273. For an influential account of South Africa's broader social rights jurisprudence, see Brian Ray, Engaging with Social Rights: Procedure, Participation and Democracy in South Africa's Second Wave (Cambridge University Press, 2016).

110. Recall the sources at supra note 61. This is one point that I discuss in further detail in $\mathrm{Da}$ Silva, Pluralist, supra note 14.

111. See e.g. Maested, Rakner \& Ferraz, supra note 109; Shylashri Shankar \& Oratap Bhanu Mehta, "Courts and Socioeconomic Rights in India" in Gauri \& Brinks, supra note 61, 146 at 155, 173; S Muralidhar, "India: The Expectations and Challenges of Judicial Enforcement of Social Rights" in Langford, supra note 14, 102. All three note that the right in India is imperfectly realized but reference other cases where positive rights avoid disaster.

112. See e.g. the discussion of the right to health in Eleanor D Kinney, "The International Human Right to Health: What Does This Mean for Our Nation and World?" (2001) 34 Ind L Rev 1457 at 1465. 
of the comparative work on the practical implications of such rights is newer or better developed than before. ${ }^{113}$

It is debatable which experience is most likely to appear in Canada. Countries that saw benefits from recognition of positive rights may differ from Canada in important ways. For instance, while the right to health care is rightly lauded for strengthening access to medicines in many states, that result may not generalize to Canada. Suggestions that South Africa, Indonesia, South Sudan, the Philippines, Malaysia, Somalia, Afghanistan, and Uganda provide "models for other settings" are unlikely to apply in Canada. ${ }^{114}$ While there is ample reason to critique the Canadian health care system, there is also good reason to prefer it to the systems in these "models" of the implementation of a constitutional right to health care. The benefits of the recognition of constitutional rights in those states are themselves debatable. While the right to health care services in South Africa, for example, has not led to any public policy disasters and was famously used to ensure that HIV medicines would be available in the country despite government opposition to their use, even that right has a checkered past in securing access to even basic health care. ${ }^{115}$ This is partly a function of government compliance with social rights norms in South Africa being subject to a "reasonableness" standard, whereby governments do not need to fulfill even a minimum core of social rights but need to take only reasonable steps to fulfill them. ${ }^{116}$ This standard may help to avoid concerns about catastrophe, but it does so at the expense of providing narrower rights than many desire. Those who seek expansive rights may find this sobering and question whether social rights will be worth it. At the same time, however, the fact that the right did not lead to financial disaster in countries with fewer resources further undermines past concerns about a lack

113. Note the dates of the texts, supra notes 61,102-103, and 111. Even recognition of the right to health has increased since Chaoulli, supra note 22. See e.g. S Katrina Perehudoff, Brigit Toebes \& Hans Hogerzeil, "Essential Medicines in National Constitutions: Progress Since 2008” (2016) 18 Health \& Hum Rts 141.

114. For an example of such a suggestion, see Perehudoff, Alexandrov \& Hogerzeil, supra note 58 at 1 .

115. See supra note 109.

116. Ibid. For the "minimum core" concept, see General Comment No. 3: The nature of states parties obligations, UNCESCROR, 5th Sess, UN Doc E/1991/23 (1990) 83 [GC 3]. That standard, too, is subject to criticism. See e.g. Katharine G Young, "The Minimum Core of Social and Economic Rights: A Concept in Search of Content” (2008) 33 Yale J Intl L 113 [Young, "The Minimum Core"]. The point here is that "reasonableness" may not require minimal content. However, the legal standards may also be coalescing. See Forman et al, supra note 53. 
of judicial competence to address relevant issues, positive rights leading to gross misallocation of resources, or co-option.

Weighing these considerations to determine whether positive rights are "worth it" is a difficult task, and arguments that these considerations are best left to other branches of government are compelling; but the possibility of rights recognition without disaster undermines some concerns about the recognition of positive rights, including those motivating past judicial reluctance towards recognition. There is, at least, enough new evidence about how to recognize those rights to justify a new outcome under the institutional norms of precedent. The considerations already discussed suggest that judges can be competent to adjudicate positive rights and provide guidance on which tools judges can and should use to avoid bad outcomes. Taking on this task may be acceptable if courts cannot avoid making determinations on social policy matters. ${ }^{117}$ Courts may be duty-bound to ensure that positive rights are recognized in a manner that secures their benefits and minimizes their detriments. ${ }^{118}$ But comparative law at least supports a much narrower conclusion: If the SCC did not "open the door" to recognition due to concerns about possible negative effects, there is now sufficient data to demonstrate that those effects need not be realized. Opening the door with proper institutional safeguards would not violate SCC norms.

Some of this foreign experience was known circa Gosselin - positive rights had been recognized elsewhere for decades prior $^{119}$ — but increased knowledge of their implications could help to justify change. The mere fact that some states recognize positive rights may not undermine judicial worries. Knowledge about which circumstances lead to disaster and which do not is also necessary to undermine concerns. Comparative data was at best less developed around the time of Gosselin. New information likely meets the standard required for change.

117. Jackman, “Chaoulli," supra note 9.

118. Ibid.

119. Positive rights existed in several states even prior to modern international human rights law's recognition of the same. Consider the facts that the Constitution of the Irish Free State, written in 1922, included several positive rights. See Mary Ann Glendon, "The Forgotten Crucible: The Latin American Influence on the Universal Human Rights Idea" (2003) 16 Harv Hum Rts J 27 at 35; John Tobin, The Right to Health in International Law (Oxford University Press, 2012) at 22. Both Glendon and Tobin note that social rights were introduced into several Latin American constitutions in the 1930s. At minimum, positive rights were widely recognized by the turn of this century. Kinney, supra note 112 . 
After all, the record on assisted death was not uniformly positive. ${ }^{120}$ The possibility of recognition without disaster and some guidance on how to bring it about sufficed. If there is insufficient reason to justify positive rights-related changes, that may be a reason to question the law of precedent, which is an independently interesting finding that further supports the present inquiry. There is at least enough new evidence about positive constitutional rights to justify reconsidering recognition thereof.

Foreign law supports the recognition of only a limited number of positive rights that are subject to safeguards, but such recognition is possible in Canada. Our comparative data suggest that relevant rights must be narrowly tailored but recognized at a more systemic level subject to the norms of stare decisis. Luckily, Canadian courts already adopt stare decisis such that like cases will be treated alike, thereby avoiding overlitigation. ${ }^{121}$ Recognition of the importance of reasonableness-like limitations on positive rights to avoid calamity and epistemic humility about how positive rights will actually operate in Canada further support adopting a gradualist and purposive approach to positive rights. Jeff King helpfully summarizes the relevant international law as part of a broader argument that gradualism can help to avoid the worst problems with positive rights: Courts must take care to set a narrow scope to positive rights in the early days of recognition to contain the possible size of unexpected consequences of recognition and to avoid the possibility of overspending. ${ }^{122}$ Setting that scope in a purposive fashion is consistent with current norms of Canadian constitutional interpretation and can further avoid problems of overlitigation and co-option. If rights recognition is limited to a small domain that is directly tied to a set interest (perhaps, as discussed below, a constitutional value), would-be claimants will know that broader claims are unlikely to succeed and will lose their motivation to spend large sums by creating unnecessary litigation or trying to secure goods that do not speak to these fundamental concerns. This narrow scope alone could avoid the misallocation problem. Where it fails, section 1 remains as a safeguard.

120. See e.g. Lemmens, "Conflict," supra note 80; Trudo Lemmens, Heesoo Kim \& Elizabeth Kurz, "Why Canada's Medical Assistance in Dying Legislation Should Be C(h)arter Compliant and What It May Help to Avoid" (2018) 11 McGill JL \& Health S61; Trudo Lemmens, "Charter Scrutiny of Canada's Medical Assistance in Dying Law and the Shifting Landscape of Belgian and Dutch Euthanasia Practice" (2018) 85 SCLR 459.

121. See Da Silva, Pluralist, supra note 14. As I noted, this remains the case even if Jeff King is right to worry that this too could lead to middle-class capture. See Jeff King, "The Future of Social Rights: Social Rights as Capstone" in Young, supra note 54, 289 at 318-19.

122. King, Social, supra note 42 at 289 (calling it "incrementalism"). 
The fact that much of the existing jurisprudence concerns a limited number of social rights also suggests that there may be sufficient transnational legal support for recognizing only a limited class of rights. Moving beyond prior scholarship, then, I submit that courts may need to be gradualists not only about the scope of rights they recognize, but also about which rights they recognize to avoid the problems above. Wider recognition of rights to education, health care, and, to a lesser but still significant extent, housing, led to a larger literature on how such rights can be realized without disaster. ${ }^{123}$ There is likely sufficient transnational evidence (and thus doctrinal support) for only this more limited class of rights. But this need not be problematic. How to realize those rights without drastic changes is also clearer than how to realize alternatives like the right to the environment, so they lend themselves to gradualism more easily than such alternatives. If courts are going to recognize positive rights, it is accordingly best to start with those rights already significantly addressed in literature, only gradually recognizing further "rights" when they are clearly necessary and practically realizable.

New international legal commitments may also support change. International legal developments have only played a small role in past Canadian jurisprudential changes. This is likely because such obligations are not formally constitutionally binding in Canada. ${ }^{124}$ Moreover, international law already recognized positive rights obligations at the time of Gosselin, ${ }^{125}$ so international law simpliciter may not support a change. Yet international law played a small role in Carter, and new Canadian international obligations could require fulfilling positive rights and serve as some evidence of a change in the circumstances in which positive rights are claimed. ${ }^{126}$ For instance, Canadian recognition of the United Nations Declaration on the Rights of Indigenous Peoples could constitute a change in Canada's understanding of its commitments-including its health care commitments— towards Indigenous Canadians. ${ }^{127}$ Subsequent changes in Indigenous rights jurisprudence can serve as further evidence that any changes in the structure of parallel Charter rights is doctrinally justifiable and advisable to

123. On the extent of their recognition, see e.g. Rosevear, Hirschl \& Jung, supra note 54. I cite many examples of the relevant literatures above. Sources in supra notes 14, 42, 102, 109, and 111 are also representative.

124. Recall my earlier commentary regarding international law, supra note 51.

125. See e.g. International Covenant on Economic, Social and Cultural Rights, 99 UNTS 3, UNGAOR, 16 December 1966. This covenant and the interpretation thereof in GC 3 predate Gosselin. See GC 3, supra note 116; Gosselin, supra note 19.

126. Carter, supra note 17.

127. GA Res 295, UNGAOR, 61st Sess, Supp No 49, UN Doc A/Res/61/295 (2007). 
realize international commitments, ${ }^{128}$ especially where constitutional provisions are to be read in light of each other. ${ }^{129}$

\section{EXPERT OPINION}

There is also likely adequate academic support to warrant a change in the SCC's treatment of positive rights. The best understanding of the academic support necessary to justify a change in SCC precedent is that there needs to be new work with clear, established merit supporting novel claims or arguing for established claims in new ways, resulting in more than de minimus academic support for the final position. Alternative tests are implausible. For an initial example, note that widespread academic recognition of established distinctions with moral relevance that may impact how courts should treat an issue will not suffice. Challenges to the killing-letting die and the doing-allowing distinctions were clear and had significant support prior to Rodriguez and so could not justify the change in Carter. ${ }^{130}$ Counter-responses to the claim that these distinctions are unstable or otherwise problematic have appeared in the interim and since. ${ }^{131}$ The relevant distinctions were always available. Such a standard cannot explain observed legal changes. For another example, the SCC seems to suggest that "consensus" is desirable. Yet it also cannot be the case that some new consensus is necessary to justify change. Given shifts in the academic narrative, consensus on these distinctions is unlikely to ever occur. Moreover, we do not let majority opinion determine what counts as good academic work generally, let alone what the law should be. But some clear academic support is necessary under the Carter standard. ${ }^{132}$ The views of one idiosyncratic professor rarely warrant the status of expert opinion possessing probative value. Arguments supporting expert positions must also be novel to justify a change in the law. Otherwise, the courts could and should have taken the position into account when reaching prior judgments.

128. This can include changes in Canadian constitutional "Aboriginal" rights. See Daniels v Canada (Indian Affairs and Northern Development), 2016 SCC 12.

129. Reference Re Secession of Quebec, [1998] 2 SCR 217 at para 50.

130. This is not a work in moral philosophy, so I will not address this fascinating literature in detail here. The Stanford Encyclopedia of Philosophy article, "Doing vs. Allowing Harm," provides a good overview of relevant works and arguments. The dates of publication of the works therein make my point here clear. See Frances Howard-Snyder \& Fiona Woollard (last revised 7 July 2021), online: <plato.stanford.edu/entries/doing-allowing >. See Fiona Woollard, Doing and Allowing Harm (Oxford University Press, 2015) and its place in the literature in the year the Carter decision was released as further evidence that debate was ongoing at that time.

131. Ibid.

132. Ibid. 
We operate constitutionally on the legal fiction that all relevant material is open to the court. A literal "consensus" test is clearly too strong: Academic consensus is fictional. ${ }^{133}$

The weaker standard of "academic support necessary for change" from the previous paragraph better fits current judicial practice. Given this standard, we can state that there is enough well-regarded new academic work with novel insight to justify recognizing positive rights. More work on why we should recognize positive rights cannot itself support the case here, but its explanation of how recognition of positive rights can avoid the SCC's previous concerns about recognition may justify change.

Ample literature now demonstrates how and when the recognition of positive rights can be constitutionally implemented without calamity. For instance, several treatises provide comparative analyses of how and when states recognize positive social, economic, and cultural rights generally, and specific examples of such rights. ${ }^{134}$ They also present best practices and pitfalls for positive rights recognition, thereby providing Canadian courts with data they could use to tailor recognition. ${ }^{135}$ Other academic works provide normative arguments for judicial tools that can be used to ensure rights recognition does not disrupt the polity. King's aforementioned argument that gradualism best ensures that recognition does not lead to serious public policy failures is a notable example. ${ }^{136}$ Academic commentary on how to positively recognize rights sourced in comparative experiences was, by contrast, relatively minimal circa Gosselin. ${ }^{137}$ Numerous newer works (of which I cite only a small, representative sample) establish that the recognition of positive rights need not be as problematic as the SCC worried at that time. They also provide new arguments for how courts can recognize positive rights without creating serious problems.

Academics are far from unanimous on whether these works provide a case for recognition, but these works are widely respected and jointly provide at least some evidence that the SCC can go against its past precedent on positive rights. The case for changes in expert opinion would be stronger if there were new Royal Commission or other government reports supporting the case for recognition. Yet

133. See Rodriguez, supra note 17; Bedford, supra note 15. Both sources contain passages that could be read as requiring that literal consensus is necessary, but one should avoid such a reading given the implausibility of any substantive claim being capable of securing actual consensus (with the possible exception of some banalities).

134. See e.g. the cited texts, supra note 102.

135. Ibid.

136. King, Social, supra note 42. He applies the argument to Canada (ibid at 109-10).

137. Compare the dates of academic volumes above. See Gosselin, supra note 19. 
the large post-Gosselin academic literature suffices to justify change on this lemma of the past precedent test. Academic works that could have grounded arguments for recognition of positive rights at the time of prior cases do not undermine the value of new academic works as evidence for the current possibility of legal recognition. Academic arguments for the recognition of positive rights under the Charter existed at the time of Gosselin. ${ }^{138}$ They continued to be available in later cases. ${ }^{139}$ Arguments that could ground recognition of such rights, such as works denying the existence or moral relevance of a positive rights-negative rights distinction, were also available circa Gosselin. ${ }^{140}$ Perhaps the courts can and should have considered these works in previous cases and chose not to do so. This would not undermine the present case. The works that could best ground positive rights- e.g., by explaining how constitutional recognition can take place without extreme negative consequences - were not widely available at that time. ${ }^{141}$ While many of those works were later available circa Insite and Carter, the decisions in those cases did not require recognizing positive rights. ${ }^{142}$ The newer academic works cited here thus were not evaluated as part of positive rights analyses in either case.

New arguments showing that positive constitutional rights work in other jurisdictions and explaining how they can do so should be invoked only when necessary, as in cases where a positive right to some good is necessary to secure basic human subsistence and there is no other legal path to securing one's necessities for life. The aforementioned comparative treatises and argument from King are just a few of the resources available if and when such a claim arises. ${ }^{143}$ When (and only when) a case requiring consideration of positive rights claims arises, these works can be the bases for new arguments for positive rights considerations. Judges can then consider and weigh their arguments. Such arguments (and the academic case for positive rights more generally) do not and likely should not rely on a denial of the positive rights-negative rights distinction in vogue at the time of-and available to the court in-Gosselin. That distinction has some

138. Consider e.g. Jackman, "Right," supra note 14.

139. See e.g. supra note 14. Several of these sources predate at least one case cited above.

140. Shue's work highlighting the distinction was already a classic at that time. Supra note 43.

Holmes \& Sunstein's book contained a newer articulation of the point and was an academic bestseller not long before the case. Supra note 43.

141. See supra note 137.

142. Carter, supra note 17; Insite, supra note 24.

143. See e.g. King, Social, supra note 42. See also the cited volumes, supra note 102. Lastly, see Da Silva, Pluralist, supra note 14 . On my ambitious days, I might suggest that this source could contribute to the present analysis, but I do not presuppose its value here. 
moral value. ${ }^{144}$ The court was right not to deny it. New arguments sourced in different normative phenomena nonetheless justify a change in judicial treatment of positive rights under the Charter, at least as a matter of precedent.

New moral arguments for positive rights may also support change. Whether courts can or should adopt these moral arguments is contestable. Yet new moral arguments for positive rights likely provide at least weak support for judicial reconsideration of past outcomes. For instance, while arguments for a right to basic subsistence existed at the time of Gosselin, ${ }^{145}$ the recent literature on that purported right offers at least new variants that were not available in earlier cases.

Robert Hughes provides an example. ${ }^{146}$ Per Hughes, the lack of government provision of health care can create immoral dependence relationships. In his view, "there is an inalienable permission not to let one's life or one's health depend on other people's discretionary choices. In other words, people cannot make morally valid promises to let their lives or their health depend on other people's discretionary choices." ${ }^{147}$ Yet people are forced to either violate the law by taking private goods or depend on charity where basic health care is not publicly available. Where "the legal obligations that prohibit people from taking what they need to survive... are government-created obligations," and any "government should prevent foreseeable conflicts between the legal requirements it creates and people's inalienable permissions," this entails that the government must ensure access to basic health care. ${ }^{148}$ Hughes further holds that it requires a right to a strictly public health care system, at least where a private tier would undermine the public system's ability to ensure basic care. ${ }^{149}$ Elizabeth Ashford makes a similar, yet distinct, argument. ${ }^{150}$ Per Ashford, the lack of government provision of social goods forces some individuals to enter into "subsistence exchange contracts," which require that they give certain basic rights in order to secure access to social goods; this inevitably leads to rights violations as the person with greater power in the contractual relationship is able to impose their

144. See Michael Da Silva, "Review Essay: Jeff King, Judging Social Rights, Cambridge University Press, 2012" (2015) 9 ICLJ 463 at 470, n 47.

145. Shue, supra note 43. Again, Shue provides a classic example. See also Amartya Sen, Development as Freedom (Oxford University Press, 1999). This book also arguably qualifies.

146. "Egalitarian Provision of Necessary Medical Treatment" (2020) 24 J Ethics 55 (discussing limitations at 66).

147. Ibid at 65 .

148. Ibid at 62-63.

149. Ibid.

150. "A Moral Inconsistency Argument for a Basic Human Right to Subsistence" in Rowan Cruft, S Matthew Liao \& Massimo Renzo, eds, Philosophical Foundations of Human Rights (Oxford University Press, 2015) 515. 
will over the other, undermining basic autonomy and rights. ${ }^{151}$ Governments must ensure access to the goods necessary for basic subsistence to limit such immoral relationships. ${ }^{152}$ This line of argument continues to gain support. ${ }^{153}$ The extent to which the plausible forms of the argument favour the constitutionalization of social rights is debatable, and counterarguments are sure to proliferate in the coming years, but the line of argument at least raises new concerns that could ground claims absent in past court cases.

\section{PUBLIC OPINION}

Finally, the role of public opinion in the case for the recognition of positive Charter rights is less clear. We lack "near consensus" that recognition is necessary. Any widespread belief in positive rights to health care in Canada also existed at the time of Auton. Positive rights to housing like those in Gosselin are arguably less popular. Whether COVID-19 will continue to garner support for public programs is debatable. Public opinion, then, may not support or undermine the present case. Yet public opinion did not seem necessary to justify a change in Carter so much as supplement the case for change there, and we do not want to make rights strictly depend on democratic concerns in any case.

Given the ample changes in law, the possibility of better adjudicative facts in future cases, and changes in transnational law and academic knowledge that otherwise justify going against past precedent and deny positive elements of some Charter rights, there is likely adequate support for opening the door to the recognition of positive constitutional rights under sections 7,12 , and 15 , even absent public consensus. Pre-existing widespread support for health care rights may suggest that health rights should be the first positive rights to be recognized, but public support is not determinative of any claim here. Cases for recognition of set rights should not be based on popularity alone.

151. Ibid.

152. Ibid.

153. See e.g. Hassoun, "Defense," supra note 56 (arguing that you cannot be forced to give up your freedom for others and are forced to do so when you do not have an entitlement to health care, requiring a right to health care). 


\section{IMPLICATIONS FOR AN ALL-THINGS-CONSIDERED ANALYSIS OF POSITIVE RIGHTS}

There are likely adequate changes in the law, circumstances, and evidence that would be proffered in a modern positive rights case to warrant overcoming past jurisprudence denying that sections 7,12 , or 15 have positive elements. Yet the case is not so overwhelming that courts must recognize positive rights on pain of failing to respond to the evidence. The SCC can recognize positive rights without violating its self-defined rules of precedent. This does not mean that they must, or even should, do so. The foregoing also provides evidence that positive constitutional rights recognition is not an unqualified good. Indeed, the way in which the preceding analysis highlighted the potential benefits and pitfalls of recognizing positive rights makes the exercise valuable even if the question of positive rights recognition is not best understood as a matter of "precedent." I thus conclude with some observations on the implications of the foregoing for all-things-considered evaluations of whether and when Canadian courts can recognize positive rights.

The first thing to observe is that the application of the modern law of precedent does not require resolution of every potential issue with positive rights. There is likely a distinction between what the SCC must do to avoid critiques that it has gone against its own internal norms when recognizing positive rights and what it must do to avoid critiques that it failed to do what is justified, all things considered. This alone is an interesting finding. Note, for instance, that the arguments above did not directly address questions about why the government may owe positive duties, the nature of those duties, or the principle that links the rights holder and duty bearer. It did not explain directly why judges should have the authority to adjudicate the relevant claims. It presented conflicting evidence about the potential effects of recognition and even suggested that different arguments have different levels of jurisprudential support. One could view this lack of engagement with core concerns as evidence that the law of precedent is ill-suited to the task at hand or to general analyses of when courts should address complex constitutional issues.

Yet the second, and possibly more important, thing to observe is that my application of the test provided insight into many general issues with social rights, vindicating use of the law of precedent as (at minimum) a useful tool for framing analysis. Where courts' internal perspective also provides a relevant lens through which to conduct an analysis, this should justify my general approach. The remainder of this work accordingly examines the implications for any 
all-things-considered analyses of when and whether Canadian courts should recognize positive rights.

The considerations above addressed many conceptual and jurisprudential issues with positive rights. At the very least, they suggest that the idea of "positive rights" is not entirely conceptually confused. Even if positive rights do not fit our best understanding of what "rights" means, they serve an important normative function in the laws of many states without creating massive problems. Countries and the international legal system connect government duty bearers with rights holders through positive rights and duties in various ways. ${ }^{154}$ Transnational law cannot provide a complete account of positive rights that links all putative rights, duties, and parties possessing each. The preceding did not provide a principle explaining why positive entitlements entailing correlative duties should be recognized. The conceptual accounts of the rights identified above are accordingly incomplete. Yet there is now ample transnational and academic evidence that this does not limit or undermine the concept's value in real-world normative orders. ${ }^{155}$ Moreover, academics provide multiple good-faith accounts of how one could link the rights, duties, and parties. ${ }^{156}$ Whether judges are institutionally capable of choosing between the options remains debatable, but the accounts at least address many basic conceptual concerns about "positive rights."

"Enforcement" of these "rights" varies widely, but this is non-fatal for positive rights advocates. Some "rights" lead to enforcement that is judicially mandated and coerced, while others provide "rights" bearers with only the moral authority to critique government actors for failing to live up to their aspirations. ${ }^{157}$ While more stringent conceptual accounts of rights may find weaker forms of enforcement problematic, the preceding suggests that "positive rights" can be part of (and trigger reasons for action within) a coherent normative order. ${ }^{158}$ Those orders can then non-arbitrarily limit the scope of these rights, not only to avoid major problems but also to (at least sometimes) cause good outcomes. ${ }^{159}$ Each form of "enforcement" can operate without causing great problems and can solve some of the jurisprudential concerns about bad outcomes, such as concerns

154. See sources cited throughout Part IV, above. The sources cited in Part IV(C)(2)(i) are especially notable.

155. Ibid, especially in Part IV(C)(2)(i), above.

156. If one finds my work unpersuasive, consider e.g. arguments by Shue, King, Hughes, Ashford, and Hassoun. See e.g. Shue, supra note 43; King, supra note 42; Hughes, supra note 146;

Ashford, supra note 150; Hassoun, Global, supra note 56; Hassoun, “Defense," supra note 56.

157. Again, see sources throughout Part IV, above, especially in Part IV(C)(2)(i)-(ii).

158. Ibid. The sources in supra note 102 are particularly helpful.

159. Ibid. 
about overlitigation or misallocation of resources. ${ }^{160}$ There is, then, evidence that at least the idea of "positive rights" is not wholly conceptually confused. The presence of a claim for a good, a duty to provide it, and a second-order right to censure those who fail to fulfill the claim at least approximates the general structure of rights. ${ }^{161}$ Where one can recognize a relationship between these elements of "rights" without causing the bad outcomes motivating many challenges to the idea of "positive rights," this too addresses some conceptual and jurisprudential concerns.

Positive rights can, in other words, make sense as a conceptual matter, be limited in scope, and be institutionally recognized in ways that avoid calamity. If nothing else, attending to the law of precedent, above, was useful for helping to demonstrate these possibilities. This record also suggests that judges can recognize and evaluate positive rights without causing severe problems, at least when identifiable safeguards are in place, which helps to address some concerns about judicial competence without fully resolving them. This record could pair with existing statements that provide at least quasi-textual support for recognizing positive rights to further address some institutional legitimacy concerns, though it will again do so in only a limited way. For instance, combining Gosselin's aforementioned recognition of section 7's possible positive elements; aspirational statements about adequate access to social goods in the equalization payments provision of the Constitution Act, 1982; Indian jurisprudence suggesting that the "right to life" entails a right to health care; and reasonably positive outcomes in India provides the framework for a textually and empirically justified recognition of a right that can be limited by section 1 to avoid misallocation concerns. ${ }^{162}$ Yet, clearly, much more needs to be done to establish that such a claim would be institutionally legitimate.

Positive rights recognition under provisions other than section 7 may gain less support. My analysis of section 7 said little about why non-discrimination law should entail positive entitlements, even if it identified changes in the context of arguments therefor. The lack of a clear explanation of why section 15 ought

160. Ibid.

161. This addresses the point I discuss above. See supra note 44.

162. See e.g. The Honourable Senator Noël A Kinsella, "Can Canada Afford a Charter of Social and Economic Rights? Toward a Canadian Social Charter" (2008) 71 Sask L Rev 7 (suggesting that s 36(1) of the Constitution Act, 1982, could be used to fashion social rights in Canada). See Equalization and Regional Disparities, Part III of the Constitution Act, 1982, being Schedule B to the Canada Act 1982 (UK), 1982, c 11. Reading that provision in tandem with the Charter could produce a reading analogous to that of the equivalent in India. For the Indian cases and commentary, see supra notes 21, 111. 
to include positive rights absent direct statutory entitlements should worry advocates where Eldridge was their biggest victory to date. ${ }^{163}$ Section 12 , in turn, likely has the strongest case for change under the "new legal arguments" branches of the precedent test, but the lack of section 12 jurisprudence can cut both ways in precedent-based and all-things-considered determinations on whether to recognize positive entitlements. ${ }^{164} \mathrm{~A}$ strict reading of the protection against cruel and unusual treatment could include positive content, ${ }^{165}$ but there is little knowledge of this phrase in the constitutional literature, let alone support for positive content under it. The fact that only one other state recognizes a right against cruel and unusual treatment limits any possible transnational support for recognition or evidence of its value. ${ }^{166}$

Still other considerations above suggest that recognizing positive rights may not be an unalloyed good. Note, for instance, that some concerns about positive rights were ultimately realized in other countries. ${ }^{167}$ The very conflicting data that allowed courts to recognize positive rights leave many questions about the institutional competence of courts unaddressed. Stating that positive rights need not be a bad thing clearly does not entail that they will be a good thing. Even moves that address some problems concerning scope, overlitigation, et cetera could leave others intact. Whether judges should be allowed to determine which outcome is more likely remains a live issue.

The lack of a clear principle for when and why positive rights should be recognized also leaves several issues unaddressed but simultaneously identifies a useful burden for analyzing judicial decisions. Absent a full defence of a plausible potential principle above, some conceptual coherence concerns may remain. Absent an explanation of which principle courts can and should adopt, courts will not only face concerns about institutional capacity but also about how they can recognize some positive rights and not others. Absent an explanation of how that principle fits within the overarching constitutional architecture, claims that positive rights lack jurisprudential support will retain their force. Yet this outcome simply identifies a useful new burden for justified positive rights recognition as an all-things-considered matter: Courts that wish to recognize any positive rights must choose principle justifying recognition of those rights and

163. Auton's limitation on Eldridge may otherwise remain operative. See Auton, supra note 31; Eldridge, supra note 30.

164. Recall Part IV(A), above.

165. Refugee Care, supra note 28.

166. Per a survey of Constitute (a repository of constitutions), only Trinidad and Tobago have an equivalent. "Constitutions" (last visited 23 July 2021), online: <www.constituteproject.org>.

167. Sources in supra notes 102, 109 are again relevant. 
explain why the courts are institutionally competent to, and jurisprudentially justified in, adopting that principle.

Luckily, the preceding also limits the principles available in judicial determinations and, by extension, the rights that can be recognized while also identifying tools for limiting their application to avoid the pitfalls of positive rights recognition outlined above. Advocates should appeal to them when making new constitutional claims. Comparative law suggests that some principles work better than others. For instance, simply treating "health" as a goal led to overly expansive entitlements. ${ }^{168} \mathrm{~A}$ lower level of well-being may be better chosen. The importance of international legal obligations in establishing the possibility of new claims further suggests that a chosen principle should be consistent with international norms. "Dignity" will gain support on both accounts; it explicitly appears in international legal documents and is a more circumscribed level of well-being. ${ }^{169}$ "Equality of opportunity" and "subsistence" may be equally compelling, ${ }^{170}$ but claims to higher levels of well-being will be more difficult to justify, given international limitations recognizing that countries are bound to recognize only a "minimum core" of rights in the first instance. ${ }^{171}$ The importance of novelty may also limit claims to principles that were not put forward in past cases or were subsequently shown to be capable of being limited. ${ }^{172}$ Yet this

168. See e.g. Maested, Rakner \& Ferraz, supra note 109 (discussing Brazil and Colombia); Alicia Ely Yamin, Oscar Parra-Vera \& Camilla Gianella, "Colombia: Judicial Protection of the Right to Health: An Elusive Promise?" in Yamin \& Gloppen, supra note 61. Cf Everaldo Lamprea, "Colombia’s Right-to-Health Litigation in a Context of Health Care Reform" in Flood \& Gross, supra note 14. Cf Jackman, "Right," supra note 14.

169. See Da Silva, "Goal," supra note 14. On the international legal status, note that it is the first value mentioned in the first modern human rights text, see Universal Declaration of Human Rights, GA Res 217 (111), UNGAOR, 3rd Sess, Supp No 13, UN Doc A/810 (1948) Preamble.

170. For good overviews of different options, see Nicole Hassoun, "The Human Right to Health" (2015) 10 Phil Compass 275; Benedict E Rumbold, "Review article: the moral right to health" 20 Crit Rev Intl Soc \& Pol Phil 508. I also explore some in Michael Da Silva, "The Complex Structure of Health Rights" (2020) 13 Public Health Ethics 99 [Da Silva, "Complex"]. Recall Hughes, Ashford, and Hassoun for good subsistence-based views. See e.g. Hughes, supra note 146; Ashford, supra note 150; Hassoun, Global, supra note 56; Hassoun, "Defense," supra note 56. For equality of opportunity-based views, see Sen, supra note 145; Amartya Sen, The Idea of Justice (Harvard University Press, 2009); Jennifer Prah Ruger, Health and Social Justice (Oxford University Press, 2009); Jennifer Prah Ruger, Global Health Justice and Governance (Oxford University Press, 2018).

171. See GC 3, supra note 116; Young, "The Minimum Core," supra note 116; Forman et al, supra note 53.

172. E.g. some equality of opportunity-based texts in note 170 predate cases like Carter, supra note 17. 
need not be problematically limiting. New evidence may establish that concerns with the use of past principles no longer apply. For instance, the availability of dignity-based arguments in Gosselin will not bar the use of that principle if there is new evidence of how it can be limited. ${ }^{173}$

While one may worry that the existing jurisprudence does not provide sufficient insight into which principles courts should select, the foregoing avoids the implications of this concern by demonstrating how courts can limit the application of any principle to avoid its worst potential implications. The importance of gradualism here cannot be overstated. Comparative legal data suggests that rights should be narrowly tailored and subject to clear limitations if they are going to avoid the worst implications of recognition seen elsewhere. This alone warrants use of section 1 to provide broad governmental latitude in social policy determinations even where their actions implicate positive rights. ${ }^{174}$ Lingering concerns about judicial competence and legitimacy in these arenas further support this gradualist approach. ${ }^{175}$ Ample deference is due during section 1 analyses if jurisprudential concerns about positive rights are not going to be realized. ${ }^{176}$ As I argued above, these concerns also suggest that gradualism should guide what rights to recognize. ${ }^{177}$

Evidentiary burdens can, thankfully, fulfill this safeguarding role even if principles ultimately cannot. For instance, some may worry that recognizing a right to health care and not a right to water is ad hoc on any plausible principle for recognizing positive rights. This may be true as a matter of moral theory. ${ }^{178}$ I take no stand on that issue here. Yet gradualism in respect of which rights to constitutionally recognize remains appropriate in the actual contexts in which principles of selection will be realized, because rights recognition in those contexts is subject to evidentiary norms. Not all values need to be recognized in, or even best realized through, constitutional rights.

This form of gradualism requires difficult judicial line drawing but does not go beyond the classical judicial role. Hierarchically ordering parts of positive rights is not beyond judicial competence. Judges make distinctions between

173. Gosselin, supra note 19.

174. I defend this view in subsections of this article devoted to "Transnational Law" and "Expert Opinion." As I note above, Jeff King was especially influential on my gradualist approach to social rights recognition. See King, Social, supra note 42. Those subsections also cite works on which I built my view.

175. Ibid.

176. Ibid.

177. Ibid.

178. Da Silva, "International," supra note 53 (responding to this challenge). 
parts of rights all the time. This is what they did when they said that positive rights do not exist under the Charter. We now have a clear test for recognition: There must be evidence to suggest that institutionally realizing these "rights" will serve some good (or at least avoid catastrophes) to justify institutionalizing the values as constitutional rights. Evidence that widespread constitutionalization of socio-economic or other positive rights can avoid these concerns is limited.

While section 1 would always safeguard against recognition of problematic positive rights, evidence of similar provisions' abilities to do so is compelling in only a few cases. Even the small number of rights that have some evidentiary support have it only when they are drafted in a circumscribed manner and subject to stringent limitation clauses. ${ }^{179}$ Gradualism should guide which rights to recognize, how to scope the rights, and how much to defer to courts in decisions about the minimalist content of this small number of positive rights. Courts should start with that limited number of rights. This form of gradualism is not only most likely to avoid the concerns above but is also most consonant with existing Canadian evidentiary norms.

One may still worry that no principle will permit this gradualist approach to the recognition of positive constitutional rights (and the content thereof), let alone do so in a manner consistent with existing international and constitutional norms. Yet if the preceding demonstrated only that courts need to make a choice about which principle to select, this is an important finding for all-things-considered analyses of whether or when to recognize positive rights. It at least raises interesting questions about institutional competence and legitimacy worth analyzing in future publications. The finding that recognition of positive rights can avoid serious issues from precedent and all-things-considered perspectives only where gradualism operates sets an additional burden on recognition that will operate in future debates. Perhaps no principle(s) can address all the issues above. The foregoing at least establishes clear criteria for a successful account that are worth exploring further.

One promising path for potential positive rights recognition that speaks to what judges are tasked with viewing is particularly worthy of future exploration. There is, in short, a good-faith argument that recognizing some positive rights could fulfill the broader purpose of the Charter. Human dignity is a core example

179. Again, see the subsections of this article devoted to "Transnational Law" and "Expert Opinion," in Parts IV(C)(2)(i)-(ii), above. Note especially concerns with broad entitlements in and around supra notes 102-15, 120-22. 
of a Canadian constitutional value. ${ }^{180}$ Yet the Charter does not currently ensure that all Canadians have even prima facie entitlements to the goods necessary to live in dignity. One cannot even secure access to basic health care or housing with existing Charter jurisprudence. ${ }^{181}$ This appears normatively problematic, if not incoherent, where social rights recognition need not entail the kind of negative outcomes, such as misallocation of public goods, that could produce further affronts to dignity. All constitutional rights are supposed to be read purposively. ${ }^{182}$ One purpose of Charter rights is to realize constitutional values. Where some positive entitlements are necessary to realize constitutional values, we should read constitutional rights as being at least capable of creating prima facie entitlements thereto- and leave concerns about negative consequences to section 1 analyses. This path thus appeals to constitutional values as the method of identifying positive rights. It is supported by several considerations above.

Conflicting social science data raises questions about judicial competence on social policy, but judges are best placed to assess constitutional values. Those values provide a plausible story about the relationship between the government and the governed that can justify some positive rights and help to address some conceptual concerns. The constitutional values-based approach allows courts to distinguish between competing claims in way that does not clearly extend beyond the appropriate judicial role. It is not as if courts can set established hierarchies without guidance. Courts must instead appeal to underlying constitutional values (as in any constitutional case).

Appealing to constitutional values likely best explains the relationship between rights bearers and duty bearers in a circumscribed manner. Recognized constitutional values, like dignity, need not entail recognition of expansive positive rights that can raise problems elsewhere. The "rights" necessary to have basic dignity are more circumscribed than those recognized in other approaches, such as the "equality of opportunity" approach. ${ }^{183}$ Appealing to these values to complete the story also addresses concerns above. There is ample transnational jurisprudence and academic work that courts can use to explain how dignitarian positive rights must be understood. Yet constitutional values are things that

180. This is clear even in the case stating that compliance with dignity cannot be a formal legal test in Canada. It can be, and remains, a constitutional value in case law. See Kapp, supra note 88 . As noted above, it is also an international value.

181. See Gosselin, supra note 19; Chaoulli, supra note 22. Again, both these cases' core claims largely remain operative.

182. See Hunter et al v Southam Inc, [1984] 2 SCR 145; Big M, supra note 48 at paras 116-17.

183. Cf Maested, Rakner \& Ferraz, supra note 109; Yamin, Parra-Vera \& Gianella supra note 170; Lamprea, supra note 170; Da Silva, "Goal," supra note 14; Da Silva, Pluralist, supra note 14. 
Canadian judges are explicitly mandated to evaluate and over which they have clear institutional competence, blunting the force of concerns that courts should not choose between competing moral principles. The genie is out of the bottle when it comes to permitting Canadian courts to evaluate constitutional values. The relevant values are, in turn, embedded in a broader constitutional architecture. This ensures that they must be read as consistent with and limited by other rights, avoiding any form of rights "imperialism" whereby a right to health care, for instance, is read as hierarchically superior to others. ${ }^{184}$ It also ensures that all rights are read in a gradualist fashion, subject to evidentiary norms, and limited by section $1 .{ }^{185}$

This path could also increase the transparency of constitutional arguments about social policy and judicial analysis thereof. In short, recognition of positive rights provides a more direct and plausible way of addressing the concerns underlying existing claims. Saying that Morgentaler, Insite, Carter, and even Chaoulli can fit under positive and negative descriptions, and that only the negative descriptions are protected, invites confusion. ${ }^{186}$ It further fails to explain the entitlements those cases seem to entail. The government needs to act to realize the outcomes of all those cases. Part of the concern in these cases is the failure to realize certain ends. It is more intellectually honest and easier to justify one's decision when one talks directly about the specific ends one seeks to protect or deny. Recognizing positive elements of rights expands our normative toolkit in a manner consistent with a plausible understanding of rights as multifaceted. ${ }^{187}$ Yet it allows us to focus on what motivates us without having to fit positive actions under implausible negative descriptions.

Much more is clearly needed to fully defend this likely controversial approach, but it accords with precedential norms insofar as it builds on existing jurisprudential posits, and safeguards like section 1 should ensure that it avoids catastrophe. The values' consistency with transnational norms provides further

184. Jennifer Prah Ruger, "Toward a Theory of a Right to Health: Capability and Incompletely Theorized Agreements" (2006) 18 Yale JL \& Human 273 at 315, n 166. See also Da Silva, "Complex," supra note 170 at 101.

185. Da Silva, Pluralist, supra note 14.

186. Morgentaler, supra note 24; Insite, supra note 24; Carter, supra note 17; Chaoulli, supra note 22.

187. Gosselin, supra note 19, Arbour J, dissenting. The dissenting opinion and academic works from Holmes and Sunstein criticize the positive/negative rights distinction, but also suggest that any plausible understanding of the positive/negative rights distinction should also recognize that at least many rights have both positive and negative elements. See Holmes \& Sunstein, supra note 43. 
support. ${ }^{188}$ It is likely the case that all positive rights have more easily realized cores and that states can take positive measures to realize them without incident. Indeed, international law already recognizes and requires this much. ${ }^{189}$ Making the relevant distinctions between different positive rights on dignitarian grounds helps to recognize and realize transnational dignitarian norms and can play a role in fulfilling international commitments.

This approach, too, is not a panacea but should contribute to ongoing debates. Any principle for recognizing positive rights will be contentious. Even if everyone were to agree that courts should appeal to dignity to interpret rights, concerns that courts will justify the recognition of too many positive rights, or that courts are not well placed to address the competing social policies that are meant to realize these rights, would remain. Moreover, nothing in the foregoing established that constitutional recognition of positive rights is wise, all things considered. Evidence that recognition of positive rights will be a good thing in Canada remains lacking, and the foregoing suggests that the textual support for recognition differs across different provisions of the constitution in any case. Even the best arguments for positive rights cannot establish that they should be constitutionally entrenched in Canada. The foregoing exercise was still useful insofar as it provided data for all-things-considered analyses.

It is also worth exploring the conditional argument for how positive rights could best be realized if analyzing the claims is unavoidable or if future constitutional drafters begin to explore the possibility of providing courts with clear textual authority to recognize positive rights. The above provided insight into how claims for positive rights can be addressed and the pitfalls of recognition. Consider Cambie. ${ }^{190}$ The SCC chose not to recognize a claimed right to health care free from lengthy wait times in Chaoulli. ${ }^{191}$ The preceding identified considerations that vindicate the outcome in the more recent trial-level decision in Cambie. ${ }^{192}$ Analyses of rights claims should meet each of the burdens identified in this article by attending to the kinds of empirical considerations highlighted in the law of precedent. This article suggests that a broad right to health care can undermine health justice. ${ }^{193}$ Whether courts are best placed to

188. See Da Silva, "Goal," supra note 14; Da Silva, Pluralist, supra note 14.

189. See GC 3, supra note 116; Young, "The Minimum Core," supra note 116; Forman et al, supra note 53.

190. Supra note 3.

191. Supra note 22.

192. Cambie, supra note 3.

193. Recall in the sources cited in the subsections of this article devoted to "Transnational Law" and "Expert Opinion," in Parts IV(C)(2)(i)-(ii), above, and my analysis in those subsections. 
determine how to realize this broad right is debatable. If there is a "right to health care," then courts should defer to governments regarding how to realize it. Striking down the core of the MPA would be questionable absent overwhelming evidence that there is a positive right to access health care from private health care providers as part of section 7 , and that health care providers must be able to serve in public and private sectors and charge for the same services in each to fulfill the right. The trial-level judgment's detailed analysis of the relevant literature was not couched in terms of positive rights, but this article suggests that the court was wise to engage with that material and not to recognize a "right" that would have had a negative impact on access to health care for many. ${ }^{194}$

New academic work and comparative legal research also undermines claims that the right to life should be interpreted as requiring a dismantling of the $M P A$. Explicit rights recognition forces us to explain the underlying normative justification for and scope of such rights and thereby helps ensure that recognition does not have self-defeating public policy implications. If we recognize positive rights, we need to set their scope and grounding. Chaoulli too, of course, can be read as a positive rights case. ${ }^{195}$ Timely access simpliciter cannot be the purpose of a right to health care. As currently understood, a right to that timely access is said to entail free-market liberties. Yet ample post-Chaoulli evidence in comparative health systems raises questions about that finding. ${ }^{196}$ Market-based health care systems produce poor health outcomes. ${ }^{197}$ While some evidence of this fact existed at the time of Chaoulli, ${ }^{198}$ additional transnational evidence combines with new evidence about the outcomes of post-Chaoulli reforms in Quebec to question earlier findings about the impact of privatization on wait times - and of

194. Ibid.

195. The judgment in Cambie reads the litigants therein as trying to build a positive rights arguments out of Chaoulli despite the earlier case's explicit denial of freestanding constitutional health rights. See Cambie, supra note 3 at para 1728; Chaoulli, supra note 22. Recall supra notes 6, 12.

196. See Flood \& Thomas, Two-Tier, supra note 9 (surveying much of the data). See also Cambie, supra note 3 at paras $2145 \mathrm{ff}$ (engaging with the data at length).

197. The ultimate market-based health care system leads to grossly inefficient and inadequate health care coverage: The USA spends more on health care per capita than other states with limited results. See Lahey, supra note 8 at 5-6. This is just one of many works that outlines the data underlining this statistical fact.

198. For contemporary commentaries, see e.g. Sujit Choudhry, "Worse than Lochner?" in Colleen M Flood, Kent Roach \& Lorne Sossin, eds, Access to Care, Access to Justice: The Legal Debate Over Private Health Insurance in Canada (University of Toronto Press, 2005) 75; Marie-Claude Prémont, "L'affaire Chaoulli et le système de santé du Québec: cherchez l'erreur, cherchez la raison" (2006) 51 McGill LJ 167. 
wait times on health. ${ }^{199}$ Courts in other post-Chaoulli cases accordingly did not recognize positive rights to short wait times or private health care provision. ${ }^{200}$ Concerns about broad rights to health care that would allow persons access to all potential health care goods likewise suggest that an unfettered right to health care can create misallocation problems. ${ }^{201}$ Indeed, if a right to health care is grounded in the need for equitable and efficient access, it is unlikely that it can allow unfettered liberty interests to undermine a public system that better ensures equitable access than "two-tiered" alternatives. ${ }^{202}$

Whether courts should decide between competing systems is, again, questionable. But insofar as courts cannot avoid choosing between them, the relevant evidential concerns limit the force of Cambie's claim. The gradualist concerns that are central to my analysis further support an approach to "health rights" that does not dismantle the public health care system. The developments I have discussed arguably cannot fully undermine Cambie's claims on their own, but they raise questions about whether the conception of the right to health care underlying the claims can address the issues with the concept of a right to health care. Indeed, the most plausible account offered in this article raises further questions about Cambie. It is difficult to see how a concern with dignity entails a moral right to "jump" a queue meant to ensure basic care for all. Cambie et al. are unlikely to meet the burdens for positive rights recognition. Recognizing this should lead claimants to be more transparent about the liberty interests motivating their claims on appeal. The evidentiary considerations in this article also likely undermine those liberty-based claims. The considerations that are relevant to the precedent in Chaoulli provide evidence against the necessity of a private health care system, rather than for it, as the trial judge recognized. I make no strong claim about that position here. It suffices to note that the difficulties of building a case for recognition in Chaoulli are likely to be resolved only by adopting an account of positive rights grounded in constitutional values and a gradualist approach to those rights. An account that includes those features is unlikely to vindicate Cambie's desired dismantling of Canada's Medicare system.

199. On the post-Chaoulli evidence, see e.g. Jackman, "Chaoulli," supra note 9 at 58.

200. See e.g. ibid at 49-50, summarizing Allen v Alberta, 2014 ABQB 184.

201. Recall the discussion of overly expansive rights in the subsection of this article on "Transnational Law." See especially notes 113-15, 167-72, and surrounding.

202. Flood \& Thomas, Two-Tier, supra note 9. This also explains the outcome at trial in Cambie. See Cambie, supra note 3. 


\section{CONCLUSION}

Attending to the law of precedent provides helpful insight into how and when Canadian courts could legitimately recognize positive rights under sections 7,12 , or 15. Application of the test for when courts may go against past constitutional precedent suggests that changes in legal standards and legislative facts likely warrant going against past SCC jurisprudence that posits that Charter rights lack positive components. The SCC can recognize positive components of Charter rights without violating its rules of precedent for constitutional cases. Yet application of the relevant test also highlights the importance of concerns animating non-recognition and the high burdens for all-things-considered justified recognition of those rights. Such recognition is most likely to occur where courts appeal to constitutional values to identify and justify positive rights, limit recognition to those that realize positive goods elsewhere, limit the scope of those rights, and provide a fair amount of deference to legislative decisions on how to realize them. If the "door" to recognition of new positive Charter rights is going to be "opened," it should be opened very gradually, and with section 1 leveraged as a safeguard against misuse. 
